\title{
Essential Oils From Cymbopogon Citratus and Lippia Sidoides in the Anesthetic Induction and Transport of Ornamental Fish Pterophyllum Scalare
}

lara Cruz de Oliveira

UFBA: Universidade Federal da Bahia

Rebeca Santos Matos Oliveira

Universidade Federal da Bahia

Carlos Henrique da Paixão Lemos

Universidade Federal da Bahia

Crislaine Palmeira Barbosa de Oliveira

Universidade Federal da Bahia

Altiery Felix e Silva

Universidade Federal da Bahia

\section{Vitor Prates Lorenzo}

Instituto Federal do Sertão Pernambucano - Campus Petrolina: Instituto Federal de Educacao Ciencia e Tecnologia do Sertao Pernambucano - Campus Petrolina

Alberto Oliveira Lima

União Metropolitana de Educação e Cultura

André Luis da Cruz

Universidade Federal da Bahia

Carlos Eduardo Copatti ( $\nabla$ carloseduardocopatti@yahoo.com.br)

Universidade Federal da Bahia https://orcid.org/0000-0002-0114-0334

\section{Research Article}

Keywords: Anesthesia, Freshwater angelfish, Gill histology, Sedation, Ventilatory rate

Posted Date: December 8th, 2021

DOI: https://doi.org/10.21203/rs.3.rs-1003771/v1

License: (c) (i) This work is licensed under a Creative Commons Attribution 4.0 International License. Read Full License

Version of Record: A version of this preprint was published at Fish Physiology and Biochemistry on April 18th, 2022. See the published version at https://doi.org/10.1007/s10695-022-01075-3. 


\section{Abstract}

This study verified the effects of essential oils from Lippia sidoides (EOLS) and Cymbopogon citratus (EOCC) on the anesthesia of freshwater angelfish (Pterophyllum scalare) of two different sizes (juveniles I $(0.82 \mathrm{~g})$ and II $(2.40 \mathrm{~g})$ ) and on the transport ( $8 \mathrm{~h})$ of juveniles II. Fish were exposed to different concentrations of EOLS and EOCC: $0,10,25,50,75,100,150,200$, and $250 \mathrm{mg} \mathrm{L}^{-1}$. Ventilatory rate (VR) and transport for $8 \mathrm{~h}$ with 0 , 10, and $15 \mathrm{mg} \mathrm{L}^{-1}$ of each essential oil were evaluated in juveniles II. The major components found in EOLS and EOCC were carvacrol $(44.50 \%)$ and a-citral $(73.56 \%)$, respectively. The best sedation and anesthesia times for both essential oils were obtained with 10 and $25 \mathrm{mg} \mathrm{L}^{-1}$ and 200 and $250 \mathrm{mg} \mathrm{L}^{-1}$ for juveniles I and II, respectively. Fish sedated with EOLS had lower VR values than the other treatments. For transported fish, blood glucose levels were higher in ornamental fish transported with 10 and $15 \mathrm{mg} \mathrm{EOLS} \mathrm{L}^{-1}$ and $15 \mathrm{mg} \mathrm{EOCC} \mathrm{L}^{-1}$. Hepatic glycogen values were higher in the control group. In general, fish transported with $10 \mathrm{mg} \mathrm{EOLS} \mathrm{L}^{-1}$ showed fewer gill histological alterations than other transported fish. When the type of lesion was evaluated, the highest gill alterations occurred in fish transported with EOCC. In conclusion, for the transport of juveniles $11,10 \mathrm{mg}$ EOLS L ${ }^{-1}$ could be used because although this concentration increased blood glucose, it decreased the VR and caused only mild alterations to the gills.

\section{Introduction}

Freshwater angelfish (Pterophyllum scalare) is one of the most attractive species of ornamental fish from continental waters for the aquarium market (Chapman et al. 1997), mainly because of its morphological diversity and color patterns (Oliveira et al. 2019a). It is an omnivorous fish with a varied diet, ingesting plankton, plants, and small invertebrates. In its natural environment (Amazon Basin), it can reach a length of up to $15 \mathrm{~cm}$ and inhabits slightly acidic waters with low hardness (Cacho et al. 1999). The species is sensitive to handling and transportation procedures (Oliveira et al. 2019a).

In this sense, anesthetics are used to reduce stress during handling and transport (short or long duration) procedures, preventing damage to the health of the fish (Hohlenwerger et al. 2016; Aydin and Barbas 2020). During transport, fish can be exposed to high-stress levels, the accumulation of excreted compounds, and reduced available dissolved oxygen (Sampaio and Freire 2016; Teixeira et al. 2018; Oliveira et al. 2019b), impairing their welfare. Fish subjected to these conditions can have undesirable side effects such as a compromised immune system, reduced growth, and mortality (Ross and Ross 2008; Souza et al. 2019).

Essential oils from medicinal plants have been recommended as anesthetics as they appear to be a safe alternative and have contributed to improved fish welfare during handling and transport (Sena et al. 2016; Teixeira et al. 2017; Limma-Netto et al, 2018; Aydin and Barbas 2020; Brandão et al. 2021). At lower concentrations, they can be used to sedation fish, increasing their tolerance to more extended periods of transport (e.g, 8 h) (Teixeira et al. 2018). The ventilatory rate (VR) evaluation is used to confirm the sedative effects of essential oils, where opercular movements are reduced in fish exposed to an anesthetic/sedative (Hohlenwerger et al. 2017; Teixeira et al. 2018).

Pepper-rosmarin (Lippia sidoides Cham. ((syn. L. origanoides)) is a shrub plant of the Verbenaceae family and endemic to northeastern Brazil. It is used in traditional medicine as an infusion or decoction due to its pharmacological actions as a sedative, anxiolytic, antifungal, antiseptic, anti-inflammatory, and muscle-relaxing 
compound (Dos Santos et al. 2015). In aquaculture, essential oil from L. sidoides (EOLS) is effective in transport and treating and combating parasites $\left(10-20 \mathrm{mg} \mathrm{L}^{-1}\right)$ and as an anesthetic (5-70 $\left.\mathrm{mg} \mathrm{L}^{-1}\right)$ to mitigate damage associated with stress from routine procedures (weighing, aquarium change and harvesting) (Soares et al. 2017; Ventura et al. 2019; Brandão et al. 2021).

Lemongrass (Cymbopogon citratus) (DC) (Stapf) is a perennial herb of the Poaceae family, native to Asia and commonly found on the American continent (Oladeji et al. 2019). Essential oil from C. citratus (EOCC) is known for its immunomodulatory, anti-inflammatory, antiseptic, antimicrobial, and antifungal properties (Devi et al. 2011; Al-Sagheer et al. 2018). In previous study, it showed efficiency as an anesthetic (200 mg L'-1) for electric blue hap (Sciaenochrmis fryeri) and labido yellow (Labidochromis caeruleus) (Kizak et al. 2018) and as an anxiolytic (10 $\mathrm{mg} \mathrm{L}^{-1}$ ) for zebrafish (Danio rerio) (Hacke et al. 2020).

Although essential oils are already widely known as anesthetics, they are foreign substances (xenobiotics) to fish organs and tissues, altering their physiological functions. The gill tissue has an extensive epithelial surface area and is in direct contact with the environment, making it the primary target of essential oils (Fernandes et al. 2007). Therefore, gill histological studies should be used to detect possible stressful effects of xenobiotics (Araujo et al. 2019; Fiedler et al. 2020). In addition, metabolic parameters such as blood glucose and muscle glycogen can be assessed in small fish $(\sim 2 \mathrm{~g})$ and provide insight into physiological changes (Oliveira et al. 2019a).

This is the first study evaluating the effects of EOLS and EOCC as anesthetics for freshwater angelfish, which have shown promising results in previous studies for other fish species (Kizak et al. 2018; Hacke et al. 2020; Monteiro et al. 2021; Brandão et al. 2021). The time taken to achieve anesthesia can vary depending on the concentration of the anesthetic (Teixeira et al. 2017) and fish weight (Diemer et al. 2012). Based on these facts, the present study evaluated the effects of different concentrations of EOLS and EOCC on sedation, induction, and anesthetic recovery in freshwater angelfish juveniles of two different sizes (juveniles I and II). Furthermore, we also evaluated the effects of these essential oils for juveniles II as sedatives on the transport (gill and metabolic changes) and, VR reduction.

\section{Material And Methods}

\section{Essential oils}

The plants to produce EOLS and EOCC were cultivated in Petrolina, PE, Brazil. The collections of the fresh leaf samples were carried out in autumn 2018. The extraction of essential oils was carried out by steam distillation using a Clevenger-type apparatus (British Pharmacopoeia 2007) for $2 \mathrm{~h}$ in the Natural Products Laboratory of the Instituto Federal do Sertão Pernambucano, Petrolina, PE, Brazil. The determination of their chemical compounds was carried out by gas chromatography/mass spectrometry (GC-MS) in the Multi-User Characterization and Analysis Laboratory of the Universidade Federal da Paraíba, João Pessoa, PB, Brazil.

The GC-MS analysis was performed using a gas chromatograph coupled to a mass selective detector (Shimadzu GCMS-QP2010 Ultra - Barueri, SP, Brazil). The capillary column was DB-5MS (Agilent technologies; $30 \mathrm{~m} \times 0.25 \mathrm{~mm} \times 0.25 \mu \mathrm{m})$. Helium (99.99\%) was used as the gas carrier. The conditions used were as follows: a constant flow of $1.1 \mathrm{~mL} \mathrm{~min}^{-1}$; injection volume of $1.0 \mu \mathrm{L}$ with injector split ratio of 1:10 $\left(250^{\circ} \mathrm{C}\right)$; electron 
impact mode at $70 \mathrm{eV}$; ion source temperature at $280^{\circ} \mathrm{C}$; and transfer line temperature at $260^{\circ} \mathrm{C}$. The oven temperature was programmed to $60^{\circ} \mathrm{C}$, with a progressive increase of $3^{\circ} \mathrm{C} \mathrm{min}-1$ until it reached $240^{\circ} \mathrm{C}$. A mixture of linear hydrocarbons $(\mathrm{C} 8 \mathrm{H} 18-\mathrm{C} 2 \mathrm{OH} 42)$ was injected under the same experimental conditions.

The identification of the essential oils constituents was realized by comparing retention indices in the equipment database (NIST, 2008) and Kovats retention index. The essential oils used in this study were the same as those used by Felix e Silva et al. (in press). The major components found for EOLS were carvacrol (44.50\%), p-cymene (14.06\%), and thymol (7.99\%); for EOCC, they were a-citral (73.56\%), myrcene (12.65\%), and geraniol (3.51\%).

\section{Location and animals}

Two different sizes of fish were tested, termed here as juveniles I (0.82 $\pm 0.02 \mathrm{~g} ; 3.24 \pm 0.05 \mathrm{~cm})$ and juveniles II $(2.40 \pm 0.08 \mathrm{~g} ; 4.78 \pm 0.05 \mathrm{~cm})$. Initially, we evaluated sedation, anesthesia induction, and anesthetic recovery times with EOLS or EOCC in juveniles I and II ( $\mathrm{n}$ total $=144$ ). Afterwards, a second experiment was performed to evaluate the effects of these essential oils on the transportation of juveniles II ( $n$ total $=48$ ). Finally, a third experiment, evaluating VR, was conducted with juveniles II $(n=40)$. For the second and third experiments, only juveniles II were selected, because juveniles I were smaller, severely impairing the analysis of blood glucose, muscle glycogen, gill histology, and VR.

The experiments were carried out in the Laboratory of Study and Physiology of Aquatic Fauna of the Universidade Federal da Bahia (UFBA) under registration no. 03-2019 at Ethical Committee of the Biology Institute of the UFBA. A total of 232 juveniles from a commercial fish farm (Lauro de Freitas, BA, Brazil) were used.

Before testing, the fish were kept in two 500-L tanks with constant aeration and mechanical and biological filters. Juveniles were fed four times a day (commercial diet, 50\% crude protein, Sera Discus Color Red, Germany) for an acclimation period of 10 days until apparent satiety. Feeding was suspended $24 \mathrm{~h}$ before the beginning of the experiments.

\section{Induction and anesthetic recovery}

The procedure involved transferring juveniles (I and II) to aquaria containing $2 \mathrm{~L}$ of water and EOLS or EOCC at concentrations of $10,25,50,75,100,150,200$, and $250 \mathrm{mg} \mathrm{L}^{-1}$ diluted $1: 10$ with absolute ethanol (1:10). Densities for EOLS and EOCC were, respectively, 0.93 and $0.90 \mathrm{~g} \mathrm{~cm}^{-3}$. A control group was transferred to aquaria containing only ethanol $\left(2,250 \mathrm{mg} \mathrm{L}^{-1}\right)$ at a concentration equivalent to the dilution used for $250 \mathrm{mg} \mathrm{L}^{-1}$ of both essential oils. A second control group with fish kept in aquariums containing only water was also performed.

In each treatment, eight juveniles I and eight juveniles II were used. For sedation (partial loss of balance and erratic swimming) and anesthesia (complete loss of balance and cessation of swimming) evaluation, two fish were simultaneously placed in each aquarium (adapted from Oliveira et al. 2019a). The fish were evaluated for up to 30 min, and each fish was used only once. Subsequently, the juveniles were transferred to a 5-L aquarium 
containing anesthetic-free dechlorinated water to measure the post-anesthetic recovery time (swimming, equilibrium and, behaviors similar to those of the fish kept in the maintenance tanks) (adapted from Sena et al. 2016). Survival was monitored up to $72 \mathrm{~h}$ after anesthetic induction.

\section{Transportation procedure}

Another 48 freshwater angelfish juveniles II were used, and five different treatments ( $\mathrm{n}=8$ fish per treatment) were evaluated: fish transported without essential oil (control) or with the addition of 10 and $15 \mathrm{mg} \mathrm{L}^{-1}$ of EOLS or EOCC. Duration of transport was $8 \mathrm{~h}$. In a pilot experiment, concentrations of $10,15,20$ and, $25 \mathrm{mg} \mathrm{L}^{-1}$ in plastic bags were used, and 20 and $25 \mathrm{mg} \mathrm{L}^{-1}$ of both essential oils showed potential to induce fish to anesthesia after $8 \mathrm{~h}$ of transport. Therefore, it was decided to use only the concentrations of 10 and $15 \mathrm{mg} \mathrm{L}^{-1}$ in this experiment, which triggered sedation, but not anesthesia, in this same transport time. Another eight juveniles were not subjected to transport and designated 'before transport'.

The fish were placed in 2-L plastic bags $(20 \times 40 \mathrm{~cm})$ closed with elastic straps containing $0.5 \mathrm{~L}$ of water and the remainder was filled with pure oxygen. The plastic bags were stored in plastic boxes for transportation in a closed car under ambient temperature $\left(30^{\circ} \mathrm{C}\right)$, simulating the routine transport of ornamental fish.

The physical and chemical parameters of the water were measured before $(0 \mathrm{~h})$ and after transportation ( $8 \mathrm{~h})$, in quadruplicate. Dissolved oxygen and temperature were measured with an oxygen meter (YSI 200A, Yellow Springs, USA) and pH meter (HmPA-210P, Piracicaba, Brazil). The hardness, carbon dioxide, chlorine and nitrite were measured with a commercial kit (JBL GmbH and Co. KG, Neuhofen, Germain) and total ammonia with another commercial kit (Alfatecnoquímica, Florianópolis, Brazil). Un-ionized ammonia levels were calculated according to a conversion table specific to freshwater.

\section{Biochemical analysis}

Blood, muscle, and gill samples were collected from eight fish per treatment before $(0 \mathrm{~h})$ and after transportation $(8 \mathrm{~h})$. Blood was collected by venocaudal puncture using heparinized syringes to determine blood glucose levels, which were analyzed using microfilm strips and a digital glucometer (Accu-Chek, Mannheim, Germany) immediately after blood collection. Then, juveniles II were euthanized with a lethal dose of benzocaine hydrochloride $\left(250 \mathrm{mg} \mathrm{L}^{-1}\right)$ (CONCEA, 2013) to collect gills and muscle.

Muscle glycogen was determined according to Bidinotto et al. (1997). The muscle samples (100 mg) were collected and preserved at $-80^{\circ} \mathrm{C}$ until analysis. These samples were homogenized in buffer $(10 \mathrm{mM}$ phosphate/20 mM tris-pH 7.0) using a mechanical homogenizer (Marconi MA039, Piracicaba, SP, Brazil) before centrifugation at $600 \mathrm{xg}$ for $3 \mathrm{~min}\left(4^{\circ} \mathrm{C}\right)$. The reading in a spectrophotometer (UV-Vis, Quimis ${ }^{\circledR}$, Diadema, Brazil) was done at $480 \mathrm{~nm}$.

\section{Gill analysis}


Gills destined for histopathologic evaluation were fixed in $10 \%$ neutral buffered formalin for $18 \mathrm{~h}$ and then washed and conditioned in $70 \%$ ethanol. Subsequently, a gill arch in each fish was removed and subdivided into three samples for histological processing ( $n=8$ fish per treatment). The samples were then dehydrated in an increasing sequence of ethyl alcohol and xylol for $1 \mathrm{~h}$, immersed in paraffin for $3 \mathrm{~h}$, and then embedded in paraffin blocks at $56^{\circ} \mathrm{C}$. The blocks were stored in a refrigerator $\left(4^{\circ} \mathrm{C}\right)$ for $12 \mathrm{~h}$ to cut posteriorly in a microtome (Zeiss Hyrax M15, Germany) with cross-sections ( $3 \mu \mathrm{m})$. After this, they were fixed on slides and submitted to staining using the hematoxylin-eosin technique (Luna 1968).

The slides were mounted in Entellan ${ }^{\circledR}$ (Merck, Darmstadt, Germany) and analyzed with a 40x objective light microscopy. Ten microphotographs per replicate were examined, totaling 80 micrographs per treatment. A digital camera (Axio Cam ICc3, Zeiss, Germain) coupled to the microscope (Axio Scope, Zeiss) and a computer was used; for analysis, we used the Axion Vision Le ${ }^{\circledR} 4.8 .2$ (Zeiss) software.

Analysis and quantification of the microphotographed samples were performed using the Cavalieri method (Mandarim-de-Lacerda 2003; Fiedler et al. 2020), which consists of an isotropic point counting system derived from a grid of points superimposed on the histological image to be analyzed. Then, the volume density (Vv) of the histological components was estimated using the following equation (adapted from Mandarim-de-Lacerda 2003):

$V_{V}(\%)=P_{P} / P_{T} \times 100$, where $P_{P}$ is the part number of test points counted on a section in relation to the total points and $\mathrm{P}_{\mathrm{T}}$ is the total number of test points lying over the references space.

A $21.0 \times 29.7-\mathrm{cm}$ rectangular grid of stitches was used to count the points, with $1 \mathrm{~cm}$ between the points to estimate the $V_{V}$ of gill tissue, secondary lamella (SL), and filament epithelium. The following $V_{V}$ of gills lesions were also estimated using the same grid size, according to Monteiro et al. (2008): hyperplasia, SL fusion, epithelial displacement, ionocyte proliferation, mucous cell proliferation, edema, hemorrhage, aneurysm, fibrosis (fibrous connective tissue), and necrosis.

Photomicrographs were also used to quantify the histopathology of gills, which were classified into three stages: I (alterations that do not affect organ functions), II (mild to moderate alterations that do not affect organ functions), and III (severe or irreversible alterations). The histopathological alteration index (HAI) was calculated according to Poleksic and Mitrovic-Tutundzic (1994), using the following equation:

$\mathrm{HAl}=\llbracket a_{\mathrm{i}}+10 \rrbracket b_{\mathrm{i}}+10^{2} \llbracket c_{\mathrm{i}}$, where HAl is the degree of alterations in a single gill, $a=$ first-stage alterations, $b=$ second-stage alterations, and $c=$ third-stage alterations.

The HAl values (\%) were considered in five categories: $<0.10=$ functionally normal gills; $0.11-0.20=$ slightly to moderately damaged gills; $0.21-0.50=$ moderately to heavily damaged gills; $0.51-1.00=$ severe injuries on gills, and $>1.00=$ irreparably damaged gills (adapted from Poleksic and Mitrovic-Tutundzic 1994).

\section{Ventilatory rate (VR)}

Juveniles II ( $n=40$, one individual per each 5-L tank), which were not used in the previous experiments, were used to assess the VR. The fish were exposed for $8 \mathrm{~h}$ to the same concentrations used in the transport procedure 
(0 (control), 10 and $15 \mathrm{mg} \mathrm{L}^{-1}$ of each essential oil). The evaluation times were: $0,0.5,1,2,3,4,5,6,7$, and 8 h. Each fish was used only once. The VR was quantified by visually counting 20 successive opercular/mouth movements, measuring the elapsed time with a stopwatch (adapted from Hohlenwerger et al. 2017).

\section{Statistical analysis}

All data are expressed as the mean \pm SEM (standard error of the mean). All data were subjected to Levene's test and the Shapiro-Wilk test to verify the homogeneity of the variances and the normality of the data, respectively. Sedation and anesthetic activity were evaluated by power regression analysis (concentration $\times$ time). Two-way analysis of variance (ANOVA) was performed (time $X$ treatment), followed by Tukey's post-hoc test for VR analysis. One-way ANOVA was performed followed by Tukey's post-hoc test to compare treatments after transport or Dunnett's test to compare these treatments with the treatment before transport. Significance was set at a critical level of $95 \%(p<0.05)$.

\section{Results}

\section{Anesthetic induction}

Freshwater angelfish juveniles I and II showed no mortality after $72 \mathrm{~h}$ of exposure to both essential oils. The application of $2.250 \mathrm{mg} \mathrm{L}^{-1}$ of ethanol alone (the concentration equivalent to the dilution used for the $250 \mathrm{mg}$ $\mathrm{L}^{-1}$ EOLS or EOCC treatment) did not induce sedation or anesthesia. Juveniles I exposed to $10 \mathrm{mg} \mathrm{L}^{-1} \mathrm{EOLS}_{\mathrm{O}}$ EOCC were sedated (Fig. 1A and 2A). In juveniles II, sedation occurred at concentrations above $25 \mathrm{mg} \mathrm{L}^{-1}$ for both essential oils (Fig. 1B and 2B).

For EOLS, juveniles I (Fig. 1C) and II (Fig. 1D) were anesthetized at concentrations above 25 and $50 \mathrm{mg} \mathrm{L}^{-1}$, respectively. For EOCC, anesthesia occurred from a concentration of $50 \mathrm{mg} \mathrm{L}^{-1}$, regardless of the size of the juveniles (Fig. 2C and 2D). No relationship was observed between the EOLS or EOCC concentrations and the duration of anesthetic recovery in juveniles I (Fig. 1E and 2E) and II (Fig. 1F and 2F).

In juveniles I, the concentration of $200 \mathrm{mg} \mathrm{L}^{-1}$ induced the shortest anesthesia and anesthetic recovery times for both essential oils. These times were, respectively, 115.38 (Fig. 1C) and 343.25 s (Fig. 1E) for EOLS and 239.25 (Fig. 2C) and $349.75 \mathrm{~s}$ (Fig. 2E) for EOCC. In juveniles II, the shortest times for anesthesia and anesthetic recovery occurred at a concentration of $250 \mathrm{mg} \mathrm{L}^{-1}$ for both essential oils. These times were, respectively, 128.88 (Fig. 1D) and $420.39 \mathrm{~s}$ (Fig. 1F) for EOLS and 163.63 (Fig. 2D) and $375.13 \mathrm{~s}$ (Fig. 2F) for EOCC.

\section{Transportation of juveniles II}

The water temperature was significantly lower in the pre-transport group compared to the transported groups. The other water quality parameters did not differ significantly between treatments (Table 1). 
Table 1

Water parameters of plastic bags with freshwater angelfish (Pterophyllum scalare) juveniles II without essential oil before e after transport ( $8 \mathrm{~h}$ ) and with essential oil from Lippia sidoides (EOLS) and Cymbopogon citratus (EOCC) added to the water after transport (8 h)

\begin{tabular}{|c|c|c|c|c|c|c|}
\hline \multirow[t]{3}{*}{ Variables } & \multirow{3}{*}{$\begin{array}{l}\text { Before } \\
\text { transport }\end{array}$} & \multicolumn{5}{|c|}{ After transport (8 h) } \\
\hline & & \multirow[t]{2}{*}{ Control } & \multirow{2}{*}{$\begin{array}{l}10 \mathrm{mg} \\
\text { EOLS L-1 }\end{array}$} & \multirow{2}{*}{$\begin{array}{l}15 \mathrm{mg} \\
\text { EOLS L-1 }\end{array}$} & \multirow{2}{*}{$\begin{array}{l}10 \mathrm{mg} \\
\mathrm{EOCC} \mathrm{L}^{-1}\end{array}$} & \multirow{2}{*}{$\begin{array}{l}15 \mathrm{mg} \\
\mathrm{EOCC} \mathrm{L}^{-1}\end{array}$} \\
\hline & & & & & & \\
\hline Temp & $28.20 \pm 0.12$ & $30.07 \pm 0.07 *$ & $29.97 \pm 0.33^{\star}$ & $\begin{array}{l}30.07 \pm \\
0.07 \star\end{array}$ & $30.17 \pm 0.03^{*}$ & $30.03 \pm 0.07 *$ \\
\hline DO & $10.81 \pm 0.23$ & $9.06 \pm 0.15$ & $9.48 \pm 0.77$ & $8.73 \pm 0.32$ & $9.03 \pm 0.29$ & $10.61 \pm 0.56$ \\
\hline $\mathrm{pH}$ & $6.82 \pm 0.03$ & $6.62 \pm 0.06$ & $6.61 \pm 0.08$ & $6.55 \pm 0.03$ & $6.58 \pm 0.05$ & $6.56 \pm 0.05$ \\
\hline Hardness & $8.00 \pm 0.29$ & $3.33 \pm 3.33$ & $3.33 \pm 0.33$ & $3.33 \pm 0.33$ & $4.00 \pm 0.29$ & $3.00 \pm 0.29$ \\
\hline $\mathrm{Cl}$ & $0.10 \pm 0.10$ & $0.27 \pm 0.27$ & $0.53 \pm 0.27$ & $0.53 \pm 0.27$ & $0.53 \pm 0.27$ & $0.53 \pm 0.27$ \\
\hline $\mathrm{CO}_{2}$ & $35.00 \pm 2.89$ & $35.00 \pm 2.89$ & $35.00 \pm 2.89$ & $31.67 \pm 3.33$ & $31.67 \pm 3.33$ & $35.00 \pm 2.89$ \\
\hline Nitrite & $0.08 \pm 0.08$ & $0.25 \pm 0.00$ & $0.25 \pm 0.00$ & $0.25 \pm 0.00$ & $0.25 \pm 0.00$ & $0.25 \pm 0.00$ \\
\hline TAM & $1.00 \pm 0.29$ & $2.67 \pm 0.83$ & $2.00 \pm 0.29$ & $2.50 \pm 0.50$ & $2.17 \pm 0.73$ & $2.17 \pm 0.73$ \\
\hline UIA & $6.42 \pm 2.09$ & $8.62 \pm 2.70$ & $6.69 \pm 1.44$ & $7.29 \pm 1.83$ & $7.28 \pm 3.16$ & $6.52 \pm 2.65$ \\
\hline \multicolumn{7}{|c|}{ 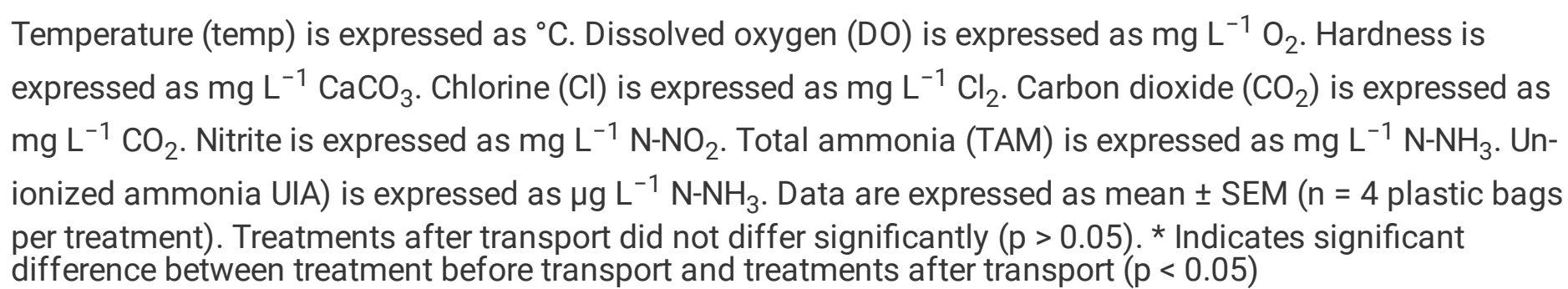 } \\
\hline
\end{tabular}

Blood glucose levels were significantly higher in the fish sedated with 10 and $15 \mathrm{mg} \mathrm{EOLS} \mathrm{L}^{-1}(\mathrm{p}<0.001$ and $p<$ 0.008 , respectively) and $15 \mathrm{mg} \mathrm{EOCC} \mathrm{L}^{-1}(\mathrm{p}=0.036)$ in relation to the group control $8 \mathrm{~h}$ after transport (Fig. 3A). Fish that were transported without the addition of essential oil (control group) had significantly higher muscle glycogen values than fish that were not transported $(p=0.003)$ or transported with 10 and $15 \mathrm{mg} \mathrm{EOLS} \mathrm{L}^{-1}(p<$ 0.001 and, 0.001 , respectively) or 10 and $15 \mathrm{mg} \mathrm{EOCC} \mathrm{L}^{-1}$ ( $p=0.002$ and, 0.001 , respectively) (Fig. 3B).

The $V_{V}$ of gills was significantly higher in treatments with $10 \mathrm{mg} \mathrm{EOLS} \mathrm{L}^{-1}$ and 10 and $15 \mathrm{mg} \mathrm{EOCC} \mathrm{L}^{-1}$ compared to values before transport ( $p=0.005,0.002$ and, 0.041 , respectively) or values in animals transported without essential oil ( $p=0.001,<0.001$ and, 0.007 , respectively) or with the addition of $15 \mathrm{mg} \mathrm{EOLS} \mathrm{L}^{-1}(p=$ $0.006,0.002$ and 0.049 , respectively). The $V_{V}$ of the secondary lamellae was significantly higher in the groups before transport or transported without the addition of essential oil or with the addition of $15 \mathrm{mg} \mathrm{EOLS} \mathrm{L}^{-1}$ than in the fish sedated with $10 \mathrm{mg} \mathrm{EOLS} \mathrm{L}^{-1}\left(p=0.049,0.004\right.$, and 0.043 , respectively). The $V_{V}$ of the filament 
epithelium in fish transported with $10 \mathrm{mg} \mathrm{EOLS} \mathrm{L}^{-1}$ and 10 and $15 \mathrm{mg} \mathrm{EOCC} \mathrm{L}^{-1}$ was significantly higher than that in animals transported with $15 \mathrm{mg}$ EOLS L-1 $(p=0.043,0.008$, and 0.017 , respectively) (Table 2).

Table 2

Gill volume density $\left(V_{V}, \%\right)$ of freshwater angelfish (Pterophyllum scalare) juveniles II without essential oil before e after transport (8 h) and with essential oil from Lippia sidoides (EOLS) and Cymbopogon citratus (EOCC) added to the water after transport $(8 \mathrm{~h})$

\begin{tabular}{|c|c|c|c|c|c|c|}
\hline \multirow{2}{*}{$\begin{array}{l}V_{V} \\
(\%)\end{array}$} & \multirow{2}{*}{$\begin{array}{l}\text { Before } \\
\text { transport }\end{array}$} & \multicolumn{5}{|c|}{ After transport ( $8 \mathrm{~h})$} \\
\hline & & Control & $\begin{array}{l}10 \mathrm{mg} \mathrm{L}^{-1} \\
\text { EOLS }\end{array}$ & $\begin{array}{l}15 \mathrm{mg} \mathrm{L}^{-1} \\
\text { EOLS }\end{array}$ & $\begin{array}{l}10 \mathrm{mg} \mathrm{L}^{-1} \\
\text { EOCC }\end{array}$ & $\begin{array}{l}15 \mathrm{mg} \mathrm{L}^{-1} \\
\text { EOCC }\end{array}$ \\
\hline GT & $35.91 \pm 1.04$ & $34.83 \pm 0.6^{b}$ & $41.99 \pm 1.49^{a, *}$ & $35.81 \pm 0.9^{b}$ & $42.50 \pm 0.88^{a, *}$ & $40.73 \pm 1.45^{\mathrm{a},{ }^{*}}$ \\
\hline SL & $30.15 \pm 2.10$ & $32.69 \pm 1.52^{\mathrm{a}}$ & $22.43 \pm 2.00^{\mathrm{b}, *}$ & $30.29 \pm 1.62^{a}$ & $25.95 \pm 2.03^{\mathrm{ab}}$ & $26.88 \pm 1.46^{\mathrm{ab}}$ \\
\hline FE & $32.80 \pm 1.95$ & $32.16 \pm 1.82^{\mathrm{ab}}$ & $37.19 \pm 1.00^{\mathrm{a}}$ & $29.69 \pm 2.44^{b}$ & $38.81 \pm 1.51^{\mathrm{a}}$ & $38.08 \pm 1.38^{\mathrm{a}}$ \\
\hline \multicolumn{7}{|c|}{$\begin{array}{l}V_{V}=\text { volume density. GT = gill tissue. } S L=\text { secondary lamella. } F E=\text { filament epithelium. Data are expressed } \\
\text { as mean } \pm \text { SEM }(n=8 \text { fish per treatment). Different letters indicate significant differences between } \\
\text { treatments after transport }(p<0.05) \text {. * Indicates significant difference between treatment before transport } \\
\text { and treatments after transport }(p<0.05)\end{array}$} \\
\hline
\end{tabular}

In all animals submitted to transport, the HAl of gills was significantly higher than those not transported in relation to stages I and II ( $p<0.001$ for both stages). In addition, for stage I, juveniles transported without the addition of essential oil $(p<0.001)$ or with the addition of $15 \mathrm{mg} \mathrm{EOLC} \mathrm{L}^{-1}(p<0.004)$ and 10 and $15 \mathrm{mg} \mathrm{EOCC}$ $\mathrm{L}^{-1}$ ( $p<0.001$ for both) had significantly higher HAl values than those transported with $10 \mathrm{mg} \mathrm{EOLS} \mathrm{L}^{-1}$. For stage III, fish transported without the addition of essential oil $(p=0.012)$ or with the addition of $15 \mathrm{mg} \mathrm{EOLS} \mathrm{L}^{-1}$, 10 and $15 \mathrm{mg} \mathrm{EOCC} \mathrm{L}^{-1}(p=0.001$ for all) had significantly higher HAl values than fish not transported (Table 3 , Fig. 4). 
Table 3

Histopathological alteration index (HAl, \%) of gills of freshwater angelfish (Pterophyllum scalare) juveniles II without essential oil before e after transport (8 h) and with essential oil from Lippia sidoides (EOLS) and Cymbopogon citratus (EOCC) added to the water after transport ( $8 \mathrm{~h}$ )

\begin{tabular}{|c|c|c|c|c|c|c|}
\hline \multirow[t]{2}{*}{ Stage } & \multirow{2}{*}{$\begin{array}{l}\text { Before } \\
\text { transport }\end{array}$} & \multicolumn{5}{|c|}{ After transport (8 h) } \\
\hline & & Control & $\begin{array}{l}10 \mathrm{mg} \text { EOLS } \\
\mathrm{L}^{-1}\end{array}$ & $\begin{array}{l}15 \mathrm{mg} \text { EOLS } \\
\mathrm{L}^{-1}\end{array}$ & $\begin{array}{l}10 \mathrm{mg} \text { EOCC } \\
\mathrm{L}^{-1}\end{array}$ & $\begin{array}{l}15 \mathrm{mg} \text { EOCC } \\
\mathrm{L}^{-1}\end{array}$ \\
\hline I & $0.03 \pm 0.00$ & $0.07 \pm 0.00^{\mathrm{a}, *}$ & $0.05 \pm 0.00^{\mathrm{b}, *}$ & $0.07 \pm 0.00^{a,{ }^{*}}$ & $0.08 \pm 0.00^{a,{ }^{*}}$ & $0.08 \pm 0.00^{a, *}$ \\
\hline II & $0.17 \pm 0.03$ & $0.41 \pm 0.05^{*}$ & $0.41 \pm 0.03^{*}$ & $0.41 \pm 0.03^{*}$ & $0.48 \pm 0.03^{*}$ & $0.50 \pm 0.04^{*}$ \\
\hline III & $0.19 \pm 0.13$ & $1.13 \pm 0.18^{*}$ & $0.89 \pm 0.26$ & $1.38 \pm 0.13^{*}$ & $1.38 \pm 0.21^{\star}$ & $1.38 \pm 0.18^{*}$ \\
\hline
\end{tabular}

Fish submitted to transport with $10 \mathrm{mg} \mathrm{L}^{-1}$ of EOLS or EOCC had significantly higher percentages for secondary lamella fusion than those not transported $(p=0.013$ and $<0.001$, respectively) or transported without the addition of essential oil ( $p=0.005$ and $<0.001$, respectively). In addition, the $10 \mathrm{mg} \mathrm{EOCC} \mathrm{L}{ }^{-1}$ treatment had significantly higher percentages of secondary lamella fusion than the $15 \mathrm{mg} \mathrm{L}^{-1}$ of EOLS or EOCC treatments ( $p$ $<0.001$ for both). Juveniles transported with $10 \mathrm{mg} \mathrm{L}^{-1}$ of EOLS or EOCC had significantly higher percentages of epithelial displacement than those belonging to the groups without the addition of essential oil before ( $p=$ 0.001 and 0.002 , respectively) or after transport ( $p<0.001$ for both). The 10 and $15 \mathrm{mg} \mathrm{EOCC} \mathrm{L}^{-1}$ treatments had significantly higher edema percentages than the pre-transport group $(p<0.006$ and 0.011 , respectively) (Table 4). 
Table 4

Volume density $\left(\mathrm{V}_{\mathrm{V}}, \%\right)$ of gills lesions of freshwater angelfish (Pterophyllum scalare) juveniles II without essential oil before e after transport $(8 \mathrm{~h}$ ) and with essential oil from Lippia sidoides (EOLS) and Cymbopogon citratus (EOCC) added to the water after transport ( $8 \mathrm{~h}$ )

\begin{tabular}{|c|c|c|c|c|c|c|}
\hline \multirow[t]{2}{*}{$\mathrm{V}_{\mathrm{V}}(\%)$} & \multirow{2}{*}{$\begin{array}{l}\text { Before } \\
\text { transport }\end{array}$} & \multicolumn{5}{|c|}{ After transport (8 h) } \\
\hline & & Control & $\begin{array}{l}10 \mathrm{mg} \text { EOLS } \\
\mathrm{L}^{-1}\end{array}$ & $\begin{array}{l}15 \text { mg EOLS } \\
L^{-1}\end{array}$ & $\begin{array}{l}10 \mathrm{mg} \text { EOCC } \\
\mathrm{L}^{-1}\end{array}$ & $\begin{array}{l}15 \mathrm{mg} \text { EOCC } \\
\mathrm{L}^{-1}\end{array}$ \\
\hline Hyperplasia & $2.45 \pm 0.67$ & $3.95 \pm 2.34$ & $6.60 \pm 1.56$ & $4.47 \pm 1.22$ & $6.15 \pm 1.67$ & $4.74 \pm 2.11$ \\
\hline SLF & $2.89 \pm 2.10$ & $1.44 \pm 0.79^{c}$ & $16.22 \pm 3.90^{a b, *}$ & $5.65 \pm 1.60^{\mathrm{bc}}$ & $25.00 \pm 3.00^{\mathrm{a},{ }^{*}}$ & $8.38 \pm 3.50^{\mathrm{bc}}$ \\
\hline ED & $8.33 \pm 2.10$ & $6.50 \pm 3.23^{b}$ & $40.60 \pm 7.13^{a_{,} *}$ & $27.20 \pm 3.70^{a b}$ & $37.40 \pm 7.10^{\mathrm{a},{ }^{\star}}$ & $20.90 \pm 4.74^{a b}$ \\
\hline IP & $8.16 \pm 0.31$ & $9.26 \pm 0.56$ & $7.24 \pm 0.38$ & $8.00 \pm 0.50$ & $7.32 \pm 0.54$ & $6.85 \pm 0.93$ \\
\hline MCP & $8.20 \pm 0.25$ & $8.05 \pm 0.89$ & $7.56 \pm 0.36$ & $8.75 \pm 0.52$ & $8.62 \pm 0.73$ & $8.35 \pm 0.72$ \\
\hline Edema & $0.26 \pm 0.06$ & $0.59 \pm 0.20$ & $0.51 \pm 0.13$ & $0.58 \pm 0.20$ & $1.00 \pm 0.14^{*}$ & $1.04 \pm 0.17^{\star}$ \\
\hline Hemorrhage & $0.96 \pm 0.09$ & $1.43 \pm 0.13$ & $0.88 \pm 0.13$ & $1.00 \pm 0.30$ & $1.01 \pm 0.20$ & $1.10 \pm 0.25$ \\
\hline Aneurysm & $0.28 \pm 0.19$ & $0.20 \pm 0.07$ & $0.15 \pm 0.04$ & $0.30 \pm 0.10$ & $0.26 \pm 0.10$ & $0.45 \pm 0.17$ \\
\hline Fibrosis & $0.20 \pm 0.08$ & $0.25 \pm 0.06^{b}$ & $0.47 \pm 0.10^{a b}$ & $0.22 \pm 0.10^{b}$ & $0.64 \pm 0.08^{a, *}$ & $0.40 \pm 0.10^{\mathrm{ab}}$ \\
\hline Necrosis & $0.27 \pm 0.06$ & $0.70 \pm 0.13$ & $0.60 \pm 0.12$ & $0.63 \pm 0.24$ & $0.77 \pm 0.15$ & $0.68 \pm 0.17$ \\
\hline $\begin{array}{l}\text { SLF = secon } \\
\text { cell prolifera } \\
\text { significant d } \\
\text { between trea }\end{array}$ & $\begin{array}{l}\text { lamella } \\
\text { Data are } \\
\text { ences bet } \\
\text { nt before }\end{array}$ & $\begin{array}{l}\text { on. DE = ep } \\
\text { oressed as } \\
\text { en treatmer } \\
\text { isport and }\end{array}$ & $\begin{array}{l}\text { lium displace } \\
\text { an } \pm \text { SEM }(n= \\
\text { after transpor } \\
\text { tments after }\end{array}$ & $\begin{array}{l}\text { th. IP = ionocy } \\
\text { sh per treatm } \\
0.05) . * \text { Indi } \\
\text { sport }(p<0.0\end{array}$ & $\begin{array}{l}\text { proliferation. } \\
\text {. Different lett } \\
\text { s significant }\end{array}$ & $\begin{array}{l}\mathrm{CP}=\text { mucous } \\
\text { s indicate } \\
\text { ference }\end{array}$ \\
\hline
\end{tabular}

Fish transported with $10 \mathrm{mg} \mathrm{EOCC} \mathrm{L}^{-1}$ had significantly higher fibrosis percentages when compared to those not transported or transported without the addition of essential oil or with the addition of $15 \mathrm{mg} \mathrm{EOCC} \mathrm{L}^{-1}\left(\mathrm{p}^{2}\right.$ $0.003,0.011$, and $<0.006$, respectively). There were no significant differences for hyperplasia, ionocytes proliferation, mucous cell proliferation hemorrhage, aneurysm, and necrosis ( $p>0.05)$ (Table 4).

\section{Ventilatory rate}

Juveniles sedated with EOLS (10 and $15 \mathrm{mg} \mathrm{L}^{-1}$ ) had significantly lower VR values than those in the other treatments ( $<$ 0.023) (except between $10 \mathrm{mg} \mathrm{EOLS} \mathrm{L}^{-1}$ and $15 \mathrm{mg} \mathrm{EOCC} \mathrm{L}^{-1}$ in $8 \mathrm{~h}$ ). In animals sedated with $15 \mathrm{mg}$ EOLS L ${ }^{-1}$, the VR was significantly higher at time $0 \mathrm{~h}$ compared to times between 5 and $8 \mathrm{~h}(\mathrm{p}<0.018)$. Additionally, for this same treatment, the VR was significantly higher at times 0.5 and $1 \mathrm{~h}$ than at $8 \mathrm{~h}(\mathrm{p}<0.001)$. For fish exposed to $10 \mathrm{mg} \mathrm{EOCC} \mathrm{L}^{-1}$, the VR was significantly higher at times 0 and $0.5 \mathrm{~h}$ compared to times between 3 and $8 \mathrm{~h}(\mathrm{p}<0.028)$. For juveniles subjected to $15 \mathrm{mg} \mathrm{EOCC} \mathrm{L}^{-1}$, the VR was significantly higher at time 0 than at times between 2 and $8 \mathrm{~h}(\mathrm{p}<0.046)$ and at time $0.5 \mathrm{~h}$ than at times between 5 and $8 \mathrm{~h}(\mathrm{p}<$ 
0.004). In addition to this same treatment, at time $1 \mathrm{~h}$, the VR was significantly higher than at time $8 \mathrm{~h}(\mathrm{p}=$ 0.003) (Fig. 5).

\section{Discussion}

The anesthetic effects of EOLS and EOCC must be attributed to their major chemical compounds (they can act together with the other compounds present), which were carvacrol and a-citral, respectively. Previous studies carried out with essential oil from Lippia alba, and EOCC (citral as the major component) in mammals demonstrated its anxiolytic and sedative action through the inhibition of the GABA receptor system ( $Y$-aminobutyric acid), an essential neurotransmitter in the brain (Costa et al. 2011; Heldwein et al. 2012; Wang and Heinbockel 2018). In addition, the evaluation of anxiolytic properties of EOCC in zebrafish indicated that GABA receptors are possibly related to the mechanism of action of their constituents (Hacke et al. 2020).

Likewise, carvacrol exerted anxiolytic and antidepressant activity and minimized excitability in the peripheral nervous system in rodents (Mello et al. 2010; Gonçalves et al. 2010). Carvacrol affects the central nervous system through GABAergic neurons through the GABA receptor, where activation of these channels promotes central nervous system depression (Mello et al. 2010; Gonçalves et al. 2010; Bianchini et al. 2017). In addition, carvacrol proved to be an efficient anesthetic for doctor fish (Garra rufa), since it did not affect electrocardiographic parameters in these fish (Aydın and Orhan 2021). Thus, a-citral and carvacrol could be involved in the mechanism of sedative and anesthetic action in fish (Heldwein et al. 2012; Bianchini et al. 2017).

Body size was also a determining factor in defining the best anesthetic concentration. The size and stage of development of fish can influence the fish response to an anesthetic (Tarkhani et al. 2016), where younger individuals, and therefore with lower body weight, would be more easily anesthetized. This was verified in the current study, where smaller individuals (juveniles I) were sedated with $10 \mathrm{mg} \mathrm{L}^{-1}$ for both essential oils, but larger individuals (juveniles II) were sedated with only $25 \mathrm{mg} \mathrm{L}^{-1}$ of EOLS or EOCC. The concentrations of both essential oils that showed the best results (based on anesthesia and recovery times) for juveniles I and II were 200 and $250 \mathrm{mg} \mathrm{L}^{-1}$, respectively. As verified for the sedation stage, again, the smaller fish required a lower concentration of essential oil to be anesthetized.

This can be explained by the fact that the gill surface of smaller fish is proportionally larger in relation to other body tissues than in larger fish (Javahery et al. 2012; Hoseini et al. 2013; Chambel et al. 2015). Thus, anesthetic absorption would occur faster in smaller fish. Similarly, in flowerhorn (Amphilophus labiatus x Amphilophus trimaculatus), fish with higher weight showed a longer anesthetic induction time with eugenol (50 mg L $\left.\mathrm{L}^{-1}\right)$ than fish with lower weight (Tarkhani et al. 2016). However, the anesthetic induction times with eugenol (50 mg L $\left.\mathrm{L}^{-1}\right)$ were similar for matrinxã (Brycon cephalus), tambaqui (Colossoma macropomum), and silver catfish with different body weights (Vidal et al. 2007; Diemer et al. 2012).

According to Ross and Ross (2008), there is usually an inverse association between metabolic rate and body weight, and therefore, larger fish require a longer exposure time and higher concentrations to be anesthetized compared to smaller ones. This was verified in the present study, as an increase in the concentration of EOLS or EOCC caused a reduction in anesthesia times for freshwater angelfish. However, concentrations above $250 \mathrm{mg}$

$\mathrm{L}^{-1}$ of both essential oils evaluated in our study should be avoided, as the use of an excessive amount of an anesthetic could affect the welfare or even cause the death of the fish (Summerfelt and Smith, 1990; Park et al. 
2008). Furthermore, an anesthetic concentration above required represents a waste of essential oil and unnecessary expenses (Teixeira et al. 2017).

According to previous studies, the ideal period for anesthesia should be close to or less than 3 min, followed by periods between 5 and 10 min for anesthetic recovery (Gilderhus and Marking, 1987; Small 2003; Ross and Ross 2008). In the present study, the recommended concentrations of EOLS presented anesthesia periods around 2 min, below the periods recommended by the previously mentioned authors. The recommended concentrations for EOCC induced anesthesia periods are between 3 and $4 \mathrm{~min}$, close to the times suggested by those authors. In addition, EOLS and EOCC can be used as anesthetics in these concentrations in biometrics and another rapid handling in these juveniles when followed by the recovery period in anesthetic-free water, as the anesthetic recovery times of both essential oils reached the recommended times.

Essential oils added to water in low concentrations can be used as sedatives during transport, reducing swimming and reaction to external stimuli in fish (Cooke et al. 2004; Sena et al. 2016). In the present study, the concentrations of both essential oils determined to transport freshwater angelfish juveniles II for $8 \mathrm{~h}$ were 10 and $15 \mathrm{mg} \mathrm{L}^{-1}$, since exposure to these concentrations only caused sedation in the fish, with no risk of anesthesia. Since fish are less agitated due to sedative substances used in the transport, essential oils can prevent more sudden changes in the water's physical-chemical parameters. Thus, fish could reduce dissolved oxygen consumption and the production of toxic nitrogen compounds (Hohlenwerger et al. 2017), which should consequently contribute to their welfare during transport. In our study, however, except for the increase in water temperature observed in all treatments subjected to $8 \mathrm{~h}$ transport, the water physical-chemical parameters were not influenced by the treatments.

In stressful situations resulting from transport, fish tend to spend more energy to maintain physiological homeostasis, which can be intensified by external factors (Teixeira et al. 2107, 2018), such as heat and vehicle movement. Therefore, the increased blood glucose levels observed in treatments with essential oil added to

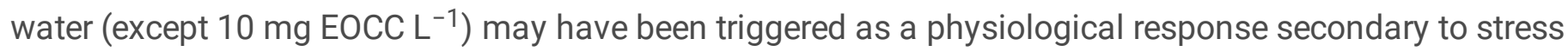
(Pankhurst 2011), allowing fish to adapt a new condition. The rise in blood glucose levels occurs immediately after the nervous system receives an adverse stimulus that will activate the hypothalamic-pituitary-interrenal axis, releasing cortisol and catecholamines into the bloodstream (Barton and Iwama 1991; Ventura et al. 2019). These hormones could have initiated metabolic processes for the use of energy reserves (Oliveira et al. 2019a) during transport in the animals of the current study. However, an increase in glucose levels does not directly correspond to an increase in blood cortisol levels. This has been verified in previous studies, with $L$. alba added to the transport water of tambacu (10 mL L-1; Sena et al. 2016) and Nile tilapia (10 mL L $\mathrm{L}^{-1}$; Hohlenwerger et al. 2017) and Aloysia triphylla added to Nile tilapia transport water (20 mL L-1; Teixeira et al. 2018), where the fish showed increased levels of glucose but not plasma cortisol after transport of $8 \mathrm{~h}$ compared to the group not transported.

Therefore, an increase in blood glucose levels could result from the breakdown of hepatic glycogen by glycogenolysis (Inoue et al. 2005), which is released as energy glucose to supply the increased metabolic demand (Perry and Capaldo 2011) during transport. The liver, and to a lesser degree, the kidney are the major sites of gluconeogenesis in fishes, and this process is unlikely to occur in skeletal muscle (Knox et al. 1980). In addition, we verified there was a reduction in muscle glycogen levels in juveniles transported with essential oil 
added to the water. The glycogen level in muscle is changeable: it is spent as required and stored up again at extra glucose intake with food (Scarabello et al. 1991). However, the elevated plasma cortisol level appears inhibit muscle glycogenesis (Milligan 2003) and muscle glycogen mobilized for muscular activity is not replenished. This physiological adjustment will consume energy, yet without compromising the individuals' survival. In contrast, in the control group, there was no mobilization of muscle glycogen. As plasma glucose levels remained stable in this treatment, excess glucose may be stored as glycogen, which could be used for other physiological functions in fish or be converted into lipids (Walker et al. 2020). Unfortunately, our study found it impossible to assess other critical physiological variables, such as hepatic glycogen and cortisol plasma levels, due to the small body size typical of freshwater angelfish. Despite this, our study's VR and gill histology analysis contributed to a better integrative interpretation of the results.

According to Balasch and Tort (2019), activation of the cerebrum-pituitary-interrenal cell metabolic axis also activates other rapid stress responses, increasing ventilatory and cardiac rate, which confer greater blood volume to the gills and muscle (Hohlenwerger et al. 2017). Therefore, a reduction in VR would reduce the possible metabolic stress in fish (Becker et al. 2018). Another possible consequence of reduced blood flow would be an energy supply to the cells, with the consequent accumulation of glucose in the blood. In the present study, both essential oils effectively reduced VR, where EOLS was more efficient than EOCC in reducing these opercular movements of freshwater angelfish juveniles II. Similarly, the use of essential oils from $L$. alba as a sedative in Nile tilapia (10-20 $\mu \mathrm{L} \mathrm{L}^{-1}$ ) (Hohlenwerger et al. 2017) and silver catfish (5-10 $\left.\mu \mathrm{L} \mathrm{L}^{-1}\right)$ (Becker et al. 2018) and from $A$. triphylla as a sedative in Nile tilapia (20-30 $\mu \mathrm{L} \mathrm{L}^{-1}$ ) (Teixeira et al. 2018) also reduced VR.

The gills are in direct contact with the environment and thus are the main target of external elements present in the water. When fish are subjected to stressful handling or transport conditions, their gills can also undergo modifications to adjust to the environment and the conditions imposed on them, guaranteeing the maintenance of their functions (Brandão et al. 2021). In our study, the groups transported without the addition of essential oil or with $15 \mathrm{mg} \mathrm{EOLS} \mathrm{L}^{-1}$ had no increase in the $\mathrm{V}_{\mathrm{V}}$ of the gills. The $\mathrm{V}_{\mathrm{V}}$ maintenance may have been influenced by an adjustment in the gill surface in these treatments. For example, an increase in the length of the lamellae and a reduction in the diffusion barrier may favor the increase in the tissue's energy demand (Perry 1998).

Fish exposed to $10 \mathrm{mg}$ EOLS L ${ }^{-1}$ during transport showed lower $\mathrm{V}_{\mathrm{V}}$ to the secondary lamella, gas exchange surface, and ion exchange in the gills (Fiedler 2020), which may indicate a lower demand for oxygen and ion exchange during transport. Additionally, the reduction in $V_{V}$ in the filament epithelium can provide a reduction in the water/blood barrier distance, reflecting in the facilitation the diffusion of respiratory gases (Mallatt 1985). In our study, a reduction in the $V_{V}$ of the filament epithelium was observed only in fish transported with $15 \mathrm{mg}$ EOLS L ${ }^{-1}$ added to water.

Early tissue damage in the gills can protect their physiological functions (Barbieri and Bondioli 2015; Brandão et al. 2021). In the present study, transported fish presented stage III lesions (severe and irreversible lesions that can severely affect vital organ functions), with HAl values higher than stages I (reversible, without damaging the gill tissues) and II (lesions severe, but reversible, with effects on associated tissue function) (Poleksic and Mitrvic-Tutundzic 1994). Nevertheless, some stage II and III lesions were dispersed and not concentrated in specific gills areas, with no indication of severe physiological damage to the fish (Poleksic and MitrovicTutundzic 1994). In addition, these lesions were less severe in fish treated with $10 \mathrm{mg} \mathrm{EOLS} \mathrm{L}^{-1}$. Similarly, 
Soares et al. (2017) found that therapeutic baths with EOLS (10 and $20 \mathrm{mg} \mathrm{L}^{-1}$ ) in tambaqui triggered some injuries, ranging from severe to irreparable for stages II and III.

The histological lesions demonstrated that the gill tissue could withstand changes according to the transport conditions in a general context. Fish transported with $10 \mathrm{mg} \mathrm{L}^{-1}$ of EOLS or EOCC had a higher $V_{V}$ of fusion in the secondary lamellae and a higher $V_{V}$ of epithelial displacement, indicating that respiratory gas diffusion in these concentrations may be reduced. Similar responses have been verified by Brandão et al. (2021) with the use of EOLS (50 $\mathrm{mg} \mathrm{L}^{-1}$ ) in tambaqui juveniles, however, without irreversible damage to the gills.

In the presence of xenobiotics, the gills can exhibit alterations that are considered defense responses (e.g., proliferation and displacement of epithelial cells, secondary lamella fusion), which can increase the water/blood distance (Monteiro et al. 2008). Therefore, when fish are exposed to environmental changes, physiological adjustments can occur in the gills to maintain the homeostasis of vital functions, such as osmoregulation, acidbase balance, excretion of nitrogen compounds, and gas exchange (Barbieri and Bondioli 2015; Brandão et al. 2021). In the present study, fish exposed to $10 \mathrm{mg} \mathrm{L}^{-1}$ of EOLS or EOCC had higher $V_{V}$ values for epithelial fusion and epithelial displacement, indicating that these alterations may have been important to guarantee the functionality of the gills.

Another critical response to environmental changes is the proliferation of mucous cells and ionocytes covering the gill surface (Wolf et al. 2015). These gill alterations can protect the pillar cells, preserving the lamellar vascular channels from external damage. However, such proliferation can also trigger an increase in the diffusion distance of $\mathrm{O}_{2}$ between respiratory epithelial cells and erythrocytes, impairing respiratory functions (Oliveira et al. 2019a). In addition to these changes, edema and fibrosis lesions are also responses to the presence of xenobiotics in the water, being considered biomarkers of acute toxicity (Monteiro et al. 2008). In our study, alterations in the proliferation of epithelial cells were not verified in the different treatments. However, in juveniles transported with EOCC, there was an increase in edema (10 or $\left.15 \mathrm{mg} \mathrm{L}^{-1}\right)$ and fibrosis $\left(15 \mathrm{mg} \mathrm{L}^{-1}\right)$ in the gills.

Finally, in the present study, although fibrosis is a severe lesion that was verified in animals exposed to $15 \mathrm{mg}$ EOCC $L^{-1}$, other severe alterations such as hemorrhage, aneurysm, and necrosis (Poleksic and MitrovicTutundzic 1994) did not differ between transported juveniles (regardless of treatment) and those before transport, indicating the potential regenerative capacity of the gill tissues. Understanding gill regenerative mechanisms in fish exposed to anesthetics require further elucidation (Kumari et al. 2020). Therefore, when selecting an essential oil with sedative capacity for fish transport, a concentration that minimizes gill damage and not cause irreversible damage to the gills needs to be favored. Thus, in our study, the treatment that reached these premises was 10 mg EOLS L ${ }^{-1}$, which can transport freshwater angelfish juvenile II for up to $8 \mathrm{~h}$, as it did not cause irreparable stage III damage to the gills.

\section{Conclusions}

We found that the developmental stage of fish can influence the action of an anesthetic. In our study, larger juvenile freshwater angelfish required a higher concentration of EOLS or EOCC to be sedated or anesthetized. For rapid handling, 200 and $250 \mathrm{mg} \mathrm{L}^{-1}$ of both essential oils are indicated for juveniles I and II, respectively. We 
also found that for the transport of juveniles II for $8 \mathrm{~h}$, the best treatment was $10 \mathrm{mg} \mathrm{EOLS} \mathrm{L}{ }^{-1}$; although this concentration increased the blood glucose levels, it decreased the VR, and no occurrences of irreversible damage to the gill tissue were recorded.

\section{Declarations}

\section{Conflict of interest}

The authors declare that they have no known competing financial interests or personal relationships that could have appeared to influence the study reported in this paper.

\section{Data availability statement}

The data that support the findings of this study are available from the corresponding author upon reasonable request.

\section{Author contribuitions}

lara C. de Oliveira and Rebeca S.M. Oliveira: carried out the experiments, biometric analyses and contribution in the results and discussion. André L. da Cruz: histological analysis, discussion of gill histopathology and final text. Carlos H.P. Lemos, Crislaine P.B. de Oliveira and Altiery Felix e Silva: biochemical analysis, collaboration on data sampling and discussion of the results. Vitor P. Lorenzo: cultivation and collection of plants to obtain essential oils. Alberto O. Lima: supervision of the experiments and facilities. Carlos E. Copatti: conception and design, supervised the findings and discussion of the results. All the authors have read and approved the manuscript.

\section{Acknowledgements}

The authors are grateful to FAPESB (Fundação de Amparo à Pesquisa do Estado da Bahia, Brazil) for a research grant provided for I. C. de Oliveira (Grant term 0407/19).

\section{References}

1. Al-Sagheer AA, Mahmoud HK, Reda FM, Mahgoub SA, Ayyat MS (2018) Supplementation of diets for Oreochromis niloticus with essential oil extracts from lemongrass (Cymbopogon citratus) and geranium (Pelargonium graveolens) and effects on growth, intestinal microbiota, antioxidant and immune activities. Aquacult Nutr 24:1006-1014. https://doi.org/10.1111/anu.12637

2. Araujo HRM, Fernandes MN, da Cruz AL (2019) Gill morphology and $\mathrm{Na}^{+} / \mathrm{K}^{+}$-ATPase activity of Gobionellus oceanicus (Teleostei: Gobiidae) in an estuarine system. Biol Trace Elem Res 187:526-535. https://doi.org/10.1007/s12011-018-1393-z

3. Aydin B, Barbas LAL (2020) Sedative and anesthetic properties of essential oils and their active compounds in fish: A review. Aquaculture 520:734999. https://doi.org/10.1016/j.aquaculture.2020.734999

4. Aydın B, Orhan N (2021) Effects of thymol and carvacrol anesthesia on the electrocardiographic and behavioral responses of the doctor fish Garra rufa. Aquaculture 553:736134.

https://doi.org/10.1016/j.aquaculture.2020.736134 
5. Barbieri E, Bondioli ACV (2015) Acute toxicity of ammonia in pacu fish (Piaractus mesopotamicus, Holmberg, 1887) at different temperatures levels. Aquacult Res 46:565-571.

https://doi.org/10.1111/are.12203

6. Balasch JC, Tort L (2019) Netting the stress responses in fish. Front Endocrinol.10:62. https://doi.org/10.3389/fendo.2019.00062

7. Barton BA, Iwama GK (1991) Physiological changes in fish from stress in aquaculture with emphasis on the response and effects of corticosteroids. Ann Rev Fish Dis 1:3-26. https://doi.org/10.1016/09598030(91)90019-G

8. Becker AJ, Fogliarini CO, Souza CF, Becker AG, Mourão RHV, Silva LVF, Baldisserotto B (2018) Ventilatory frequency and anesthetic efficacy in silver catfish, Rhamdia quelen: A comparative approach between different essential oils. Rev Bras Zoot 47:e20170185. https://doi.org/10.1590/rbz4720170185

9. Bianchini AE, Garlet QI, Da Cunha JA, Bandeira Junior G, Brusque ICM, Salbego J, Baldisserotto B (2017) Monoterpenoids (thymol, carvacrol and S-(+)-linalool) with anesthetic activity in silver catfish (Rhamdia quelen): evaluation of acetylcholinesterase and GABAergic activity. Braz J Med Biol Res 50:e6346. https://doi.org/10.1590/1414-431X20176346

10. Bidinotto PM, Moraes G, Souza RDS (1997) Hepatic glycogen and glucose in eight tropical freshwater teleost fish: A procedure for field determinations of micro samples. Bol Técn CEPTA 10:53-60

11. Brandão F, Farias CFS, De Melo Souza DC, De Oliveira MIB, De Matos LV, Majolo C, Chagas EC (2021) Anesthetic potential of the essential oils of Aloysia triphylla, Lippia sidoides and Mentha piperita for Colossoma macropomum. Aquaculture 534:736275. https://doi.org/10.1016/j.aquaculture.2020.736275

12. British Pharmacopoeia Commission (2007) British Pharmacopoeia (5th ed). The Stationery Office, London

13. Cacho MSRF, Yamamoto ME, Chellappa S (1999) Comportamento reprodutivo do acará-bandeira, Pterophyllum scalare(Osteichthyes, Cichlidae). Rev Bras Zool 16:653-664. https://doi.org/10.1590/S010181751999000300006

14. Cadiz L, Jonz MG (2020) A comparative perspective on lung and gill regeneration. J Exp Biol 223:19. https://doi.org/10.1242/jeb.226076

15. Chambel JR, Pinho R, Sousa R, Ferreira T, Baptista T, Severiano V, Mendes S, Pedrosa R (2015) The efficacy of MS-222 as anaesthetic agent in four freshwater aquarium fish species. Aquacult Res 46:1582-1589. https://doi.org/10.1111/are.12308

16. Chapman FA, Fitz-Coy SA, Thunberg EM, Adams CM (1997) United States of America trade in ornamental fish. J World Aquac Soc 28:1-10. https://doi.org/10.1111/j.1749-7345.1997.tb00955.x

17. CONCEA (2013) Diretrizes da Prática de Eutanásia do Conselho Nacional de Controle de Experimentação Animal. Ministério da Ciência, Tecnologia e Inovação, Brasília

18. Costa CRA, Kohn DO, De Lima VM, Gargano AC, Flório JC, Costa M (2011) The GABAergic system contributes to the anxiolytic-like effect of essential oil from Cymbopogon citratus (lemongrass). J Ethnopharmacol 137:828-836. https://doi.org/10.1016/j.jep.2011.07.003

19. Cooke SJ, Suski CD, Ostrand KG, Tufts BL, Wahl DH (2004) Behavioral and physiological assessment of low concentrations of clove oil anaesthetic for handling and transporting largemouth bass (Micropterus salmoides). Aquaculture 239:509-529. https://doi.org/10.1016/j.aquaculture.2004.06.028 
20. Devi RC, Sim SM, Ismail R (2011) Spasmolytic effect of citral and extracts of Cymbopogon citratus on isolated Rabbit ileum. J Smooth Muscle Res 47:143-156. https://doi.org/10.1540/jsmr.47.143

21. Diemer O, Neu DH, Bittencourt F, Signor A, Boscolo WR, Feiden A (2012) Eugenol as anesthetic for silver catfish (Rhamdia voulezi) with different weight Ciênc Agrár 33:1495-1500. https://doi.org/10.5433/1679$0359.2012 v 33 n 4 p 1495$.

22. Dos Santos CP, De Oliveira TC, Pinto JAO, Fontes SS, Cruz EMO, Arrigoni-Blank MF, Andrade TM, De Matos IL, Innecco R, Blank AF (2015) Chemical diversity and influence of plant age on the essential oil from Lippia sidoides Cham. germplasm. Ind Crops Prod 76:416-421. https://doi.org/10.1016/j.indcrop.2015.07.017

23. Felix e Silva A, Pires IC, da Costa MM, Melo JFB, Lorenzo VP, Melo FVST, Copatti CE (in press) Antibacterial and antibiofilm activities and synergism with florfenicol from the essential oils of Lippia sidoides and Cymbopogon citratus against Aeromonas hydrophila. J Appl Microb

24. Fernandes C, Fontaínhas-Fernandes A, Monteiro SM, Salgado MA (2007) Histopathological gill changes in wild leaping grey mullet (Liza saliens) from the Esmoriz-Paramos coastal lagoon, Portugal. Environ Toxicol Int J 22:443-448. https://doi.org/10.1002/tox.20269

25. Fiedler S, Wünnemann H, Hofmann I, Theobalt N, Feuchtinger A, Walch A, Blutke A (2020) A practical guide to unbiased quantitative morphological analyses of the gills of rainbow trout (Oncorhynchus mykiss) in ecotoxicological studies. Plos One 15:0243462. https://doi.org/10.1371/journal.pone.0243462

26. Gilderhus PA, Markinkg LL (1987) Comparative efficacy of 16 anesthetics chemicals on rainbow trout. North Am J Fish Manag 7:288-292. https://doi:10.1577/1548-8659(1987)7<288:CEOACO>2.0.CO;2

27. Gonçalves JCR, Aron de Miranda HA, De Araújo AEV, Cruz JS, Araújo DAM (2010) Distinct effects of carvone analogues on the isolated nerve of rats. Europ J Pharmacol 645:108-112.

https://doi.org/10.1016/j.ejphar.2010.07.027

28. Hacke ACM, Miyoshi E, Marques JA, Pereira RP (2020) Anxiolytic properties of Cymbopogon citratus (DC.) stapf extract, essential oil and its constituents in zebrafish (Danio rerio). J Ethnopharmacol 260:113036. https://doi.org/10.1016/j.jep.2020.113036

29. Heldwein CG, Silva LL, Reckziegel P, Barros FMC, Bürger ME, Baldisserotto B, Heinzmann BM (2012) Participation of the GABAergic system in the anesthetic effect of Lippia alba (Mill.) NE Brown essential oil. Braz J Med Biol Res 45:436-443. http://dx.doi.org/10.1590/S0100-879X2012007500052

30. Hohlenwerger JC, Copatti CE, Sena AC, Couto RD, Baldisserotto B, Heinzmann BM, Caron BO, Schmidt D (2016) Could the essential oil of Lippia alba provide a readily available and cost-effective anaesthetic for Nile tilapia (Oreochromis niloticus)? Mar Freshw Behav Physiol 49:119-126. https://doi.org/10.1080/10236244.2015.1123869

31. Hohlenwerger JC, Baldisserotto B, Couto RD, Heinzmann BM, Silva DT, Caron BO, Schimidt D, Copatti CE (2017) Essential oil of Lippia alba in the transport of Nile tilapia. Ciênc Rur 47:20160040. https://doi.org/10.1590/0103-8478cr20160040

32. Hoseini SM, Rajabiesterabadi H, Tarkhani R (2013) Anaesthetic efficacy of eugenol on iridescent shark, Pangasius hypophthalmus (Sauvage, 1878) in different size classes. Aquacult Res 46, 1-8. https://doi.org/10.1111/are.12188

33. Inoue LAKA, Afonso LOB, Iwama GK, Moraes G (2005) Effects of clove oil on the stress response of matrinxã (Brycon cephalus) subjected to transport. Acta Amaz 35:289-295. 
https://doi.org/10.1590/S0044-59672005000200018

34. Javahery S, Nekoubin H, Moradlu AH (2012) Effect of anaesthesia with clove oil in fish. Fish Physiol Biochem 38:1545-1552. https://doi.org/10.1007/s10695-012-9682-5

35. Kizak V, Can E, Can SS, Özçiçek E (2018) Anesthetic efficacy of Cymbopogon citratus essential oil as a herbal agent in two ornamental fish species. Isr J Aquac-Bamid 70:1505.

36. Knox D, Walton MJ, Cowey CB (1980) Distribution of enzymes of glycolysis and gluconeogenesis in fish tissues. Mar Biol 56, 7-10. https://doi.org/10.1007/BF00390588

37. Kumari P, Abidi S, Parwez I (2018) Evaluation of anaesthetizing efficacy of clove oil in Channa punctatus. Int J Fish Aquat Stud 6, 262-266.

38. Limma-Netto JD, Sena AC, Copatti CE (2018) Essential oils of Ocimum basilicum and Cymbopogon flexuosus in the sedation, anesthesia and recovery of tambacu (Piaractus mesopotamicus male $\mathrm{x}$ Colossoma macropomum female). Bol Inst Pesca 42:727-733. https://doi.org/10.20950/16782305.2016v42n3p727

39. Luna LG (1968) Manual of histologic staining methods of the Armed Forces Institute of Pathology. 3.ed. Mc Gra, New York

40. Mallatt $J$ (1985) Fish gill structural changes induced by toxicants and other irritants: A statistical review. Can J Fish Aquat Sci 42:630-648. https://doi.org/10.1139/f85-083

41. Mandarim-de-Lacerda CA (2003) Stereological tools in biomedical research. An Acad Bras Ciênc 75:469486. https://doi.org/10.1590/S0001-37652003000400006

42. Mello FHC, Venâncio ET, De Sousa DP, Fonteles MMF, De Vasconcelos SMM, Viana GSB, De Sousa FCF (2010) Anxiolytic-like effect of carvacrol (5-isopropyl-2-methylphenol) in mice: Involvement with GABAergic transmission. Fundam Clin Pharmacol 24:437-443. https://doi.org/10.1111/j.14728206.2009.00788.x

43. Milligan CL (2003) A regulatory role for cortisol in muscle glycogen metabolism in rainbow trout Oncorhynchus mykiss Walbaum. J Exp Bio/ 206:3167-3173. https://doi.org/10.1242/jeb.00538

44. Monteiro PC, Brandão FR, Farias CFS, Sebastião FA, Majolo C, Dairiki JK, Chagas EC (2021) Dietary supplementation with essential oils of Lippia sidoides, Ocimum gratissimum and Zingiber officinale on the growth and hemato-immunological parameters of Colossoma macropomum challenged with Aeromonas hydrophila. Aquac Rep 19:100561. https://doi.org/10.1016/j.aqrep.2020.100561

45. Monteiro SM, Rocha E, Fontaínhas-Fernandes A, Sousa M (2008) Quantitative histopathology of Oreochromis niloticus gills after copper exposure. J Fish Biol 73:1376-1392. https://doi.org/10.1111/j.1095-8649.2008.02009.x

46. NIST/EPA/NIH (2008) Mass Spectral Library and Search/analysis Programs, J. Wiley and Sons, Hoboken 47. Oladeji OS, Adelowo FE, Ayodele DT, Odelade KA (2019) Phytochemistry and pharmacological activities of Cymbopogon citratus: A review. Scient Afric 6:00137. https://doi.org/10.1016/j.sciaf.2019.e00137

48. Oliveira CPB, Lemos CHP, Felix e Silva A, De Souza SA, AlbinatinAC, Lima AO, Copatti CE (2019a) Use of eugenol for the anaesthesia and transportation of freshwater angelfish (Pterophyllum scalare). Aquaculture 513:734409. 10.1016/j.aquaculture.2019.734409

49. Oliveira CPB, Lemos CHP, Vidal LVO, Couto RD, Pereira DSP, Copatti CE (2019b) Anaesthesia with eugenol in hybrid Amazon catfish (Pseudoplatystoma reticulatum $\times$ Leiarius marmoratus) handling: Biochemical and 
haematological responses. Aquaculture 501:255-259. https://doi.org/10.1016/j.aquaculture.2018.11.046

50. Pankhurst NW (2011) The endocrinology of stress in fish: An environmental perspective. Gen Comp Endocrinol 170:265-275. https://doi.org/10.1016/j.ygcen.2010.07.017

51. Park MO, Hur WJ, Im SY, Seol DW, Lee J, Park IS (2008) Anaesthetic efficacy and physiological responses to clove oil anaesthetized kelp grouper Epinephelus bruneus. Aquacult Res 39:877-884.

https://doi.org/10.1111/j.1365-2109.2008.01941.x

52. Perry SF (1998) Relationships between branchial chloride cells and gas transfer in freshwater fish. Comp Biochem Physiol A 119:9-16. https://doi.org/10.1016/S1095-6433(97)00411-X

53. Perry SF, Capaldo A (2011) The autonomic nervous system and chromaffin tissue: neuroendocrine regulation of catecholamine secretion in non-mammalian vertebrates. Auton Neurosci 165:54-66. https://doi.org/10.1016/j.autneu.2010.04.006

54. Poleksic V, Mitrovic-Tutundzic V (1994) Fish gills as a monitor of sublethal and chronic effects of pollution. In: Müller R, Lloyd R (eds) Sublethal and chronic effects of pollutants on freshwater fish. FAO, Fishing News Books, Oxford, pp 339-352

55. Ross LG, Ross B (2008) Anaesthetic and sedative techniques for aquatic animals. $3^{\text {rd }}$ ed John Wiley \& Sons, Inc, New Jersey. https://doi.org/10.1002/9781444302264

56. Sampaio FD, Freire CA (2016) An overview of stress physiology of fish transport: Changes in water quality as a function of transport duration. Fish Fish 17:1055-1072. https://doi.org/10.1111/faf.12158

57. Scarabello M, Wood CM, Heigenhauseg RJF (1991) Glycogen depletion in juvenile rainbow trout as an experimental test of the oxygen debt hypothesis. Can J Zool 69:2562-2568. https://doi.org/10.1139/z91361

58. Sena AC, Teixeira RR, Ferreira,EL, Heinzmann BM, Baldisserotto B, Caron BO, Schmidt D, Couto RD, Copatti CE (2016) Essential oil from Lippia alba has anaesthetic activity and is effective in reducing handling and transport stress in tambacu (Piaractus mesopotamicus $\times$ Colossoma macropomum). Aquaculture 465:374-379. https://doi.org/10.1016/j.aquaculture.2016.09.033

59. Small BC (2003) Anesthetic efficacy of metomidate and comparison of plasma cortisol responses totricaine methanesulfonate, quinaldine and clove oil anesthetized channel catfish Ictalurus punctatus. Aquaculture 218:177-185. https://doi.org/10.1016/S0044-8486(02)00302-2

60. Souza C, Baldissera M, Baldisserotto B, Heinzmann B, Martos-Sitcha JA, Mancera JM (2019) Essential oils as stress-reducing agents for fish aquaculture: A Review. Front Physiol 10:785.

https://doi.org/10.3389/fphys.2019.00785

61. Soares BV, Neves LR, Ferreira DO, Oliveira MSB, Chaves FCM, Chagas EC, Tavares-Dias M (2017) Antiparasitic activity, histopathology and physiology of Colossoma macropomum (tambaqui) exposed to the essential oil of Lippia sidoides (Verbenaceae). Vet Parasitol 234:49-56.

https://doi.org/10.1016/j.vetpar.2016.12.012

62. Summerfelt RC, Smith LS (1990) Anesthesia, surgery, and related techniques. In Schreck CB, Moyle PB (eds) Methods for fish biology. Am Fish Soci, Bethe, pp 213-272

63. Tarkhani R, Imani A, Jamali H, Sarvi MK (2016) Anesthetic efficacy of eugenol on flowerhorn (Amphilophus labiatus x Amphilophus trimaculatus). Aquacult Res 48:3207-3215. https://doi.org/10.1111/are.13151. 
64. Teixeira RR, Souza RC, Sena AC, Baldisserotto B, Heinzmann BM, Couto RD, Copatti CE (2017) Essential oil of Aloysia triphylla in Nile tilapia: Anaesthesia, stress parameters and sensory evaluation of fillets. Aquacult Res 48:3383-3392. https://doi.org/10.1111/are.13165

65. Teixeira RR, Souza RC, Sena AC, Baldisserotto B, Heinzmann BM, Copatti CE (2018) Essential oil of Aloysia triphylla is effective in Nile tilapia transport. Bol Inst Pesca 44:17-24. https://doi.org/10.20950/16782305.2018.263

66. Ventura AS, De Castro Silva TS, Zanon RB, Inoue LAKA, Cardoso CAL (2019) Physiological and pharmacokinetic responses in neotropical Piaractus mesopotamicus to the essential oil from Lippia sidoides (Verbenaceae) as an anesthetic. Int Aquat Res 11:1-12. https://doi.org/10.1007/s40071-0190215-Z

67. Vidal LVO, Albinati RCB, Santos Neto EB, Deus BT, Albinati ACL (2007) Influência do peso de juvenis de matrinxã (Brycon cephalus) e tambaqui (Colossoma macropomum) à ação anestésica do eugenol. Rev Bras Saúde Prod Anim 8:212-216

68. Walker AM, Copatti CE, Melo FVST, Melo JFB (2020) Metabolic and physiological responses to intraperitoneal injection of chromium oxide in hyperglycaemic Nile tilapia juveniles. Aquaculture 517:734821. https://doi.org/10.1016/j.aquaculture.2019.734821

69. Wang Z-J, Heinbockel T (2018) Essential oils and their constituents targeting the GABAergic system and sodium channels as treatment of neurological diseases. Molec 23:1061.

https://doi.org/10.3390/molecules23051061

70. Wolf JC, Baumgartner WA, Blazer VS, Camus AC, Engelhardt JA, Fournie JW, Wolfe MJ (2015) Non lesions, misdiagnoses, missed diagnoses, and other interpretive challenges in fish histopathology studies: A guide for investigators, authors, reviewers, and readers. Toxicol Pathol 43:297-325.

https://doi.org/10.1177/0192623314540229

\section{Figures}


Juvenile I
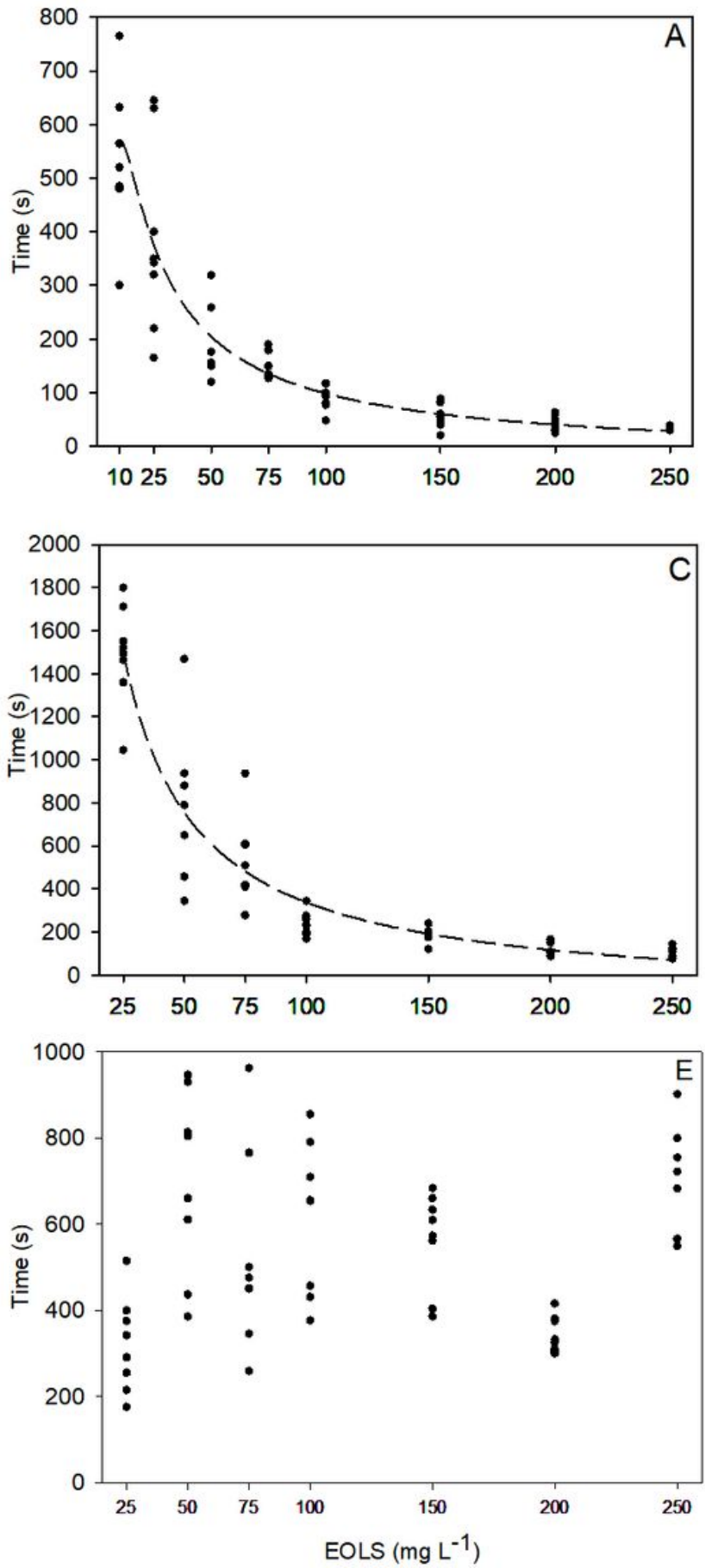

Juvenile II
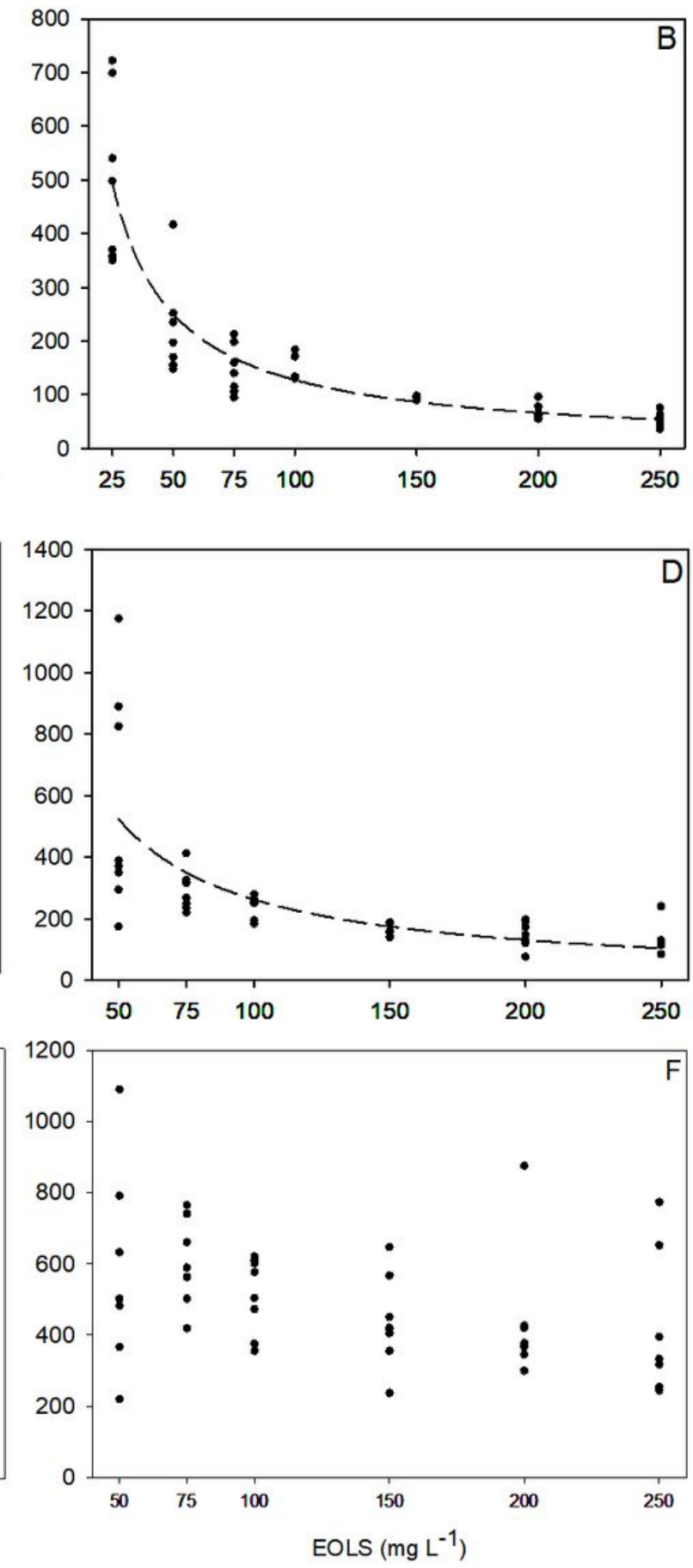

Figure 1

Time required for sedation, anesthesia, and anesthesia recovery in freshwater angelfish (Pterophyllum scalare) juveniles I ( $A, C$ and $E$, respectively) and II (B, D and $F$, respectively) with increasingly essential oil from Lippia sidoides (EOLS) concentrations ( $n=8$ fish per treatment). Equations: $A: y=5,123 x-0.884 ; R^{2}=0.84 ; B: y=$ $7,534 x-0.88 ; R^{2}=0.87 ; C: y=87,622 x-1.245 ; R^{2}=0.89 ; D: y=10,934 x-0.82 ; R^{2}=0.66$ 
Juvenile I
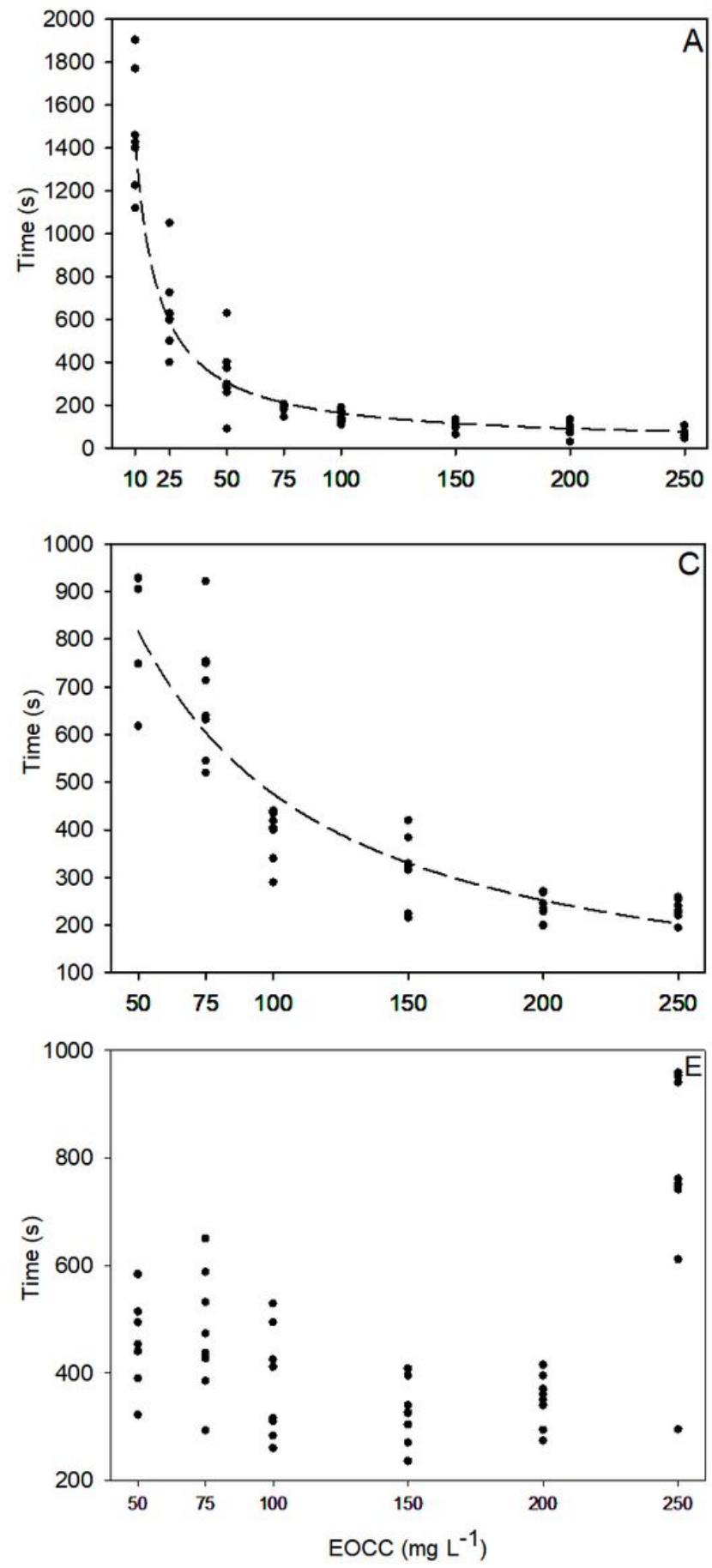

Juvenile II
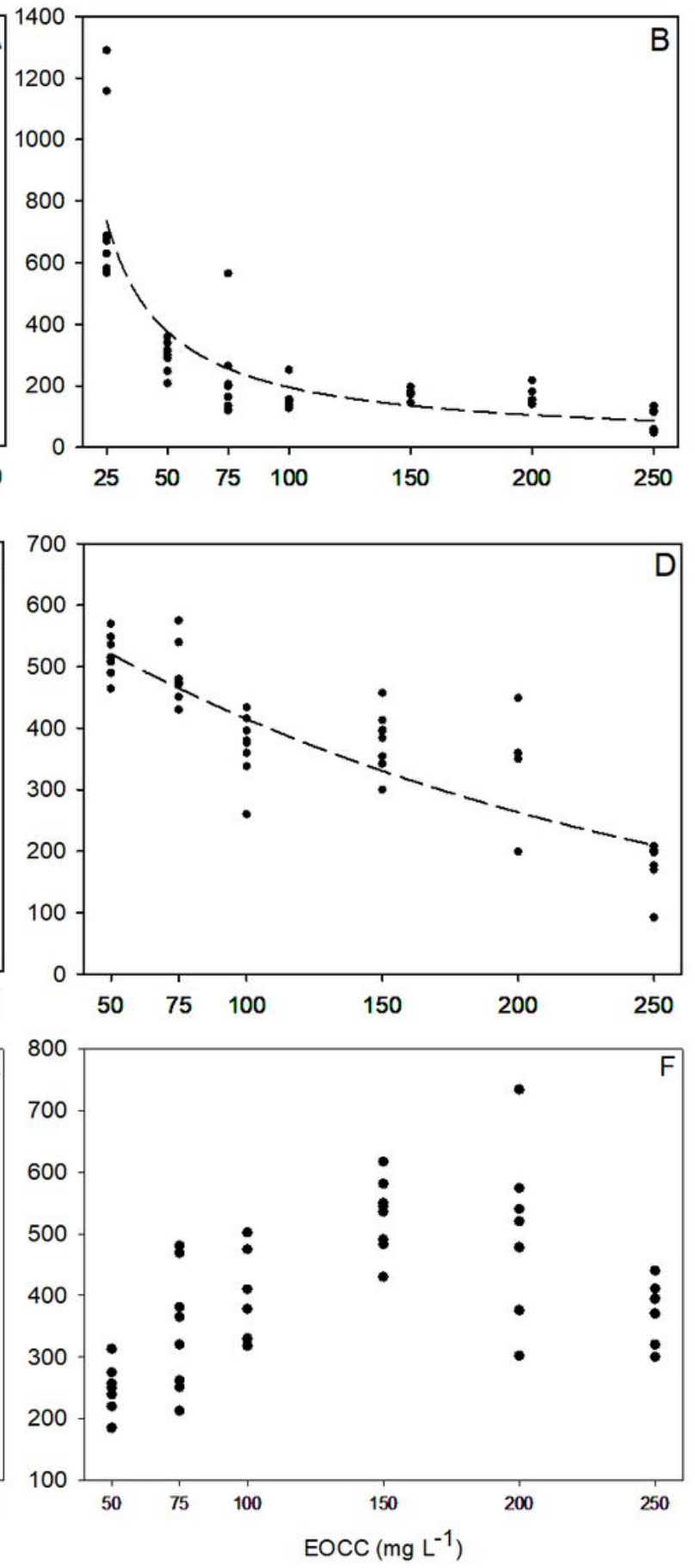

Figure 2

Time required for sedation, anesthesia, and anesthesia recovery in freshwater angelfish (Pterophyllum scalare) juveniles I (A, B and $C$, respectively) and II (D, E and F, respectively) with increasingly essential oil from Cymbopogon citratus (EOCC) concentrations ( $\mathrm{n}=8$ fish per treatment). Equations: $A: y=13331 x-0.973 ; R^{2}=$ 0.90; $B: y=7087 x-0.77 ; R^{2}=0.70 ; C: y=28029 x-0.899 ; R^{2}=0.83 ; D: y=7139 x-0.63 ; R^{2}=0.63$ 

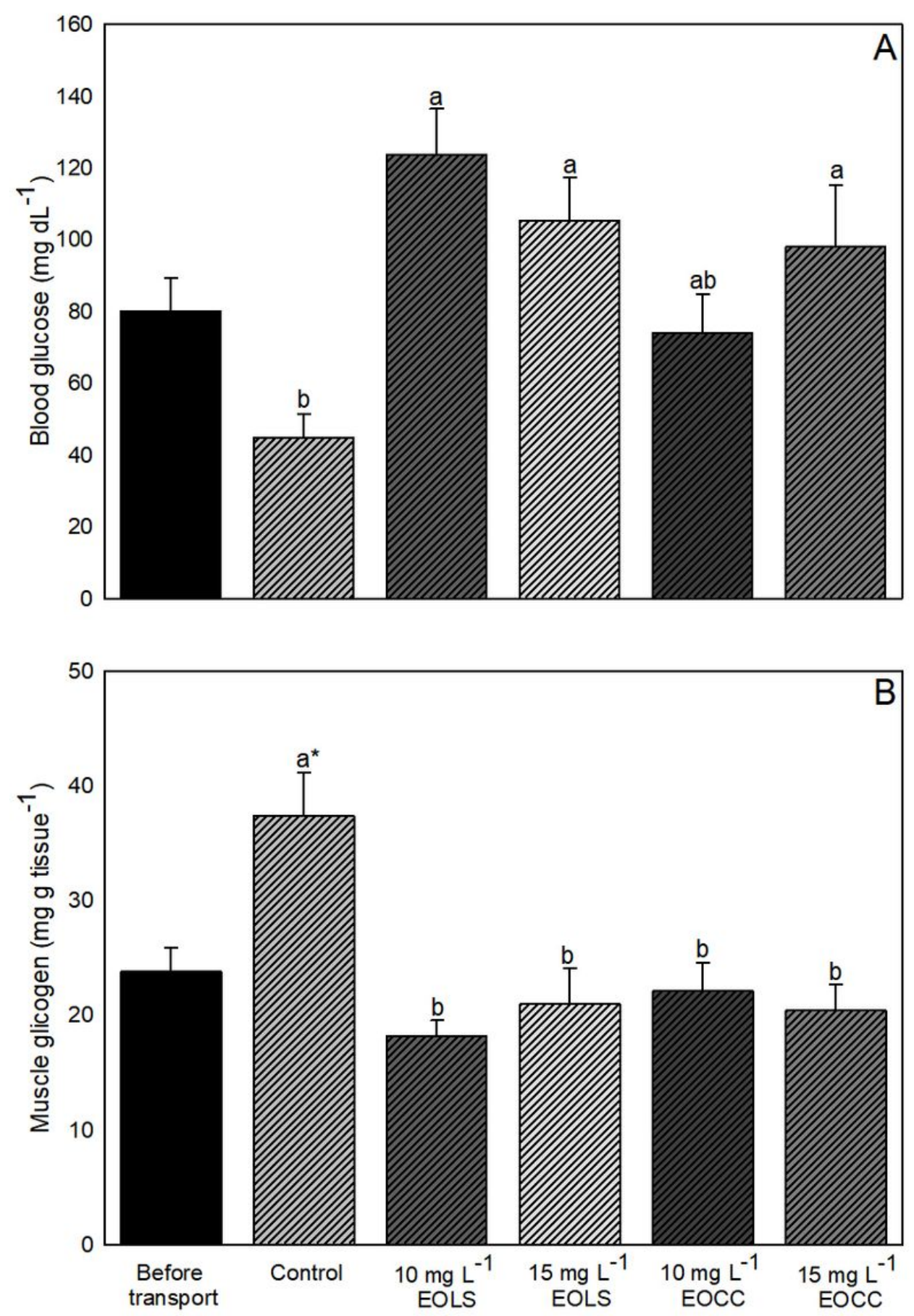

\section{Figure 3}

Blood glucose (a) and muscle glycogen (b) in freshwater angelfish (Pterophyllum scalare) juveniles II without essential oil before e after transport $(8 \mathrm{~h}$ ) and with essential oil from Lippia sidoides (EOLS) and Cymbopogon citratus (EOCC) added to the water after transport $(8 \mathrm{~h})$. Data are expressed as mean \pm SEM $(n=8$ fish per treatment). Different letters indicate significant differences between treatments after transport $(p<0.05)$. * Indicates significant difference between treatment before transport and treatments after transport $(p<0.05)$ 

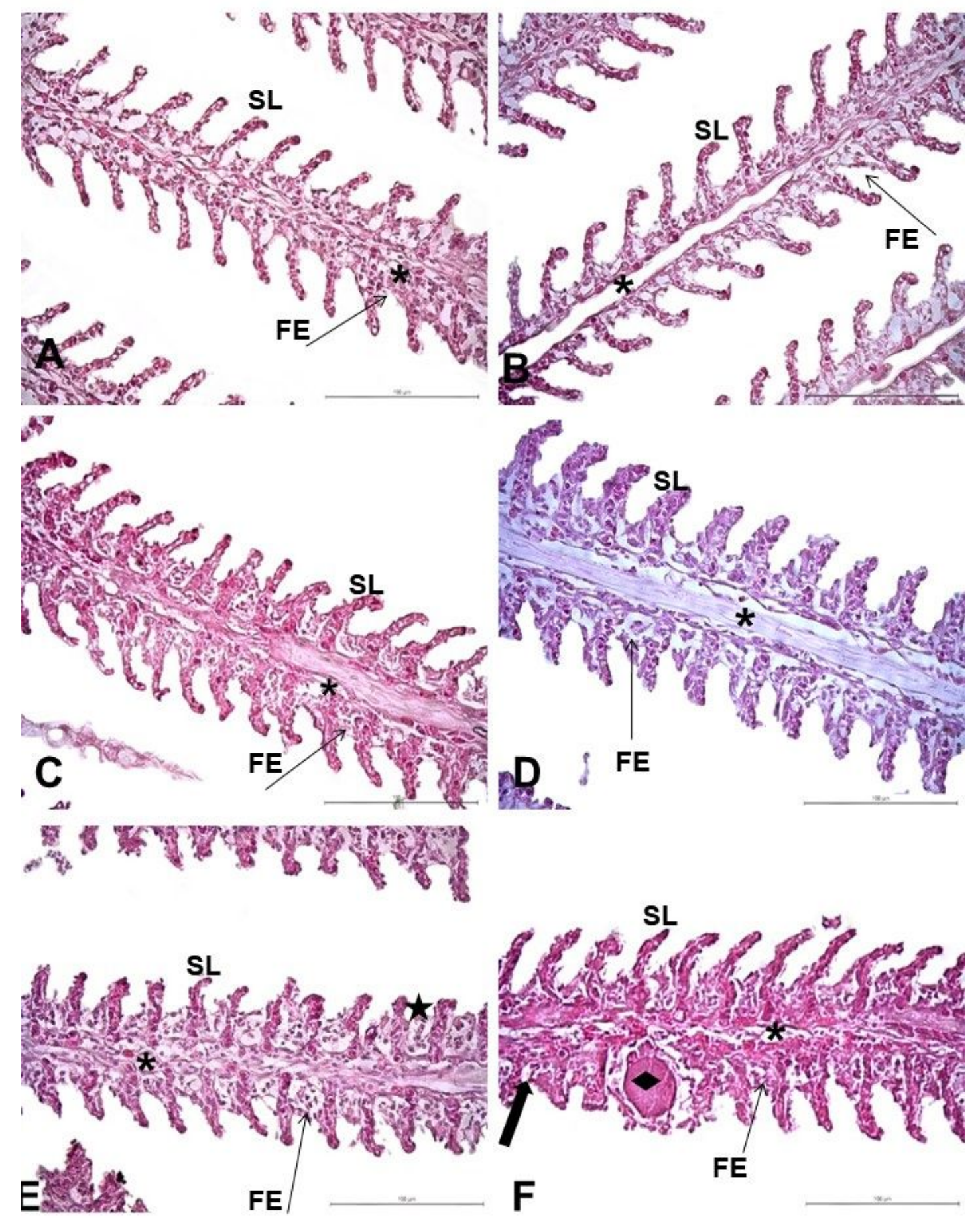

Figure 4

Histological alterations of gills in freshwater angelfish (Pterophyllum scalare) juveniles II ( $\mathrm{n}=8$ fish per treatment) without essential oil before (A) and after transport (8 h) (B) and with 10 and $15 \mathrm{mg} \mathrm{L}-1$ of essential oil from Lippia sidoides (EOLS) ( $C$ and $D$, respectively) and 10 and $15 \mathrm{mg} \mathrm{L}-1$ of essential oil from Cymbopogon citratus (EOCC) (E and F, respectively). Gills were stained with HE (magnification: 400x). Bar $=100 \mu \mathrm{m} .{ }^{*}=$ primary lamella, $\mathrm{SL}=$ secondary lamella, $\mathrm{FE}=$ filament epithelium. $\mathrm{E}$ : fish transported with $10 \mathrm{mg}$ EOCC L-1 showing hyperplasia (star). F: fish transported with $15 \mathrm{mg}$ EOCC L-1 showing shortening of the secondary lamella (large arrow) and aneurysm (diamond) 


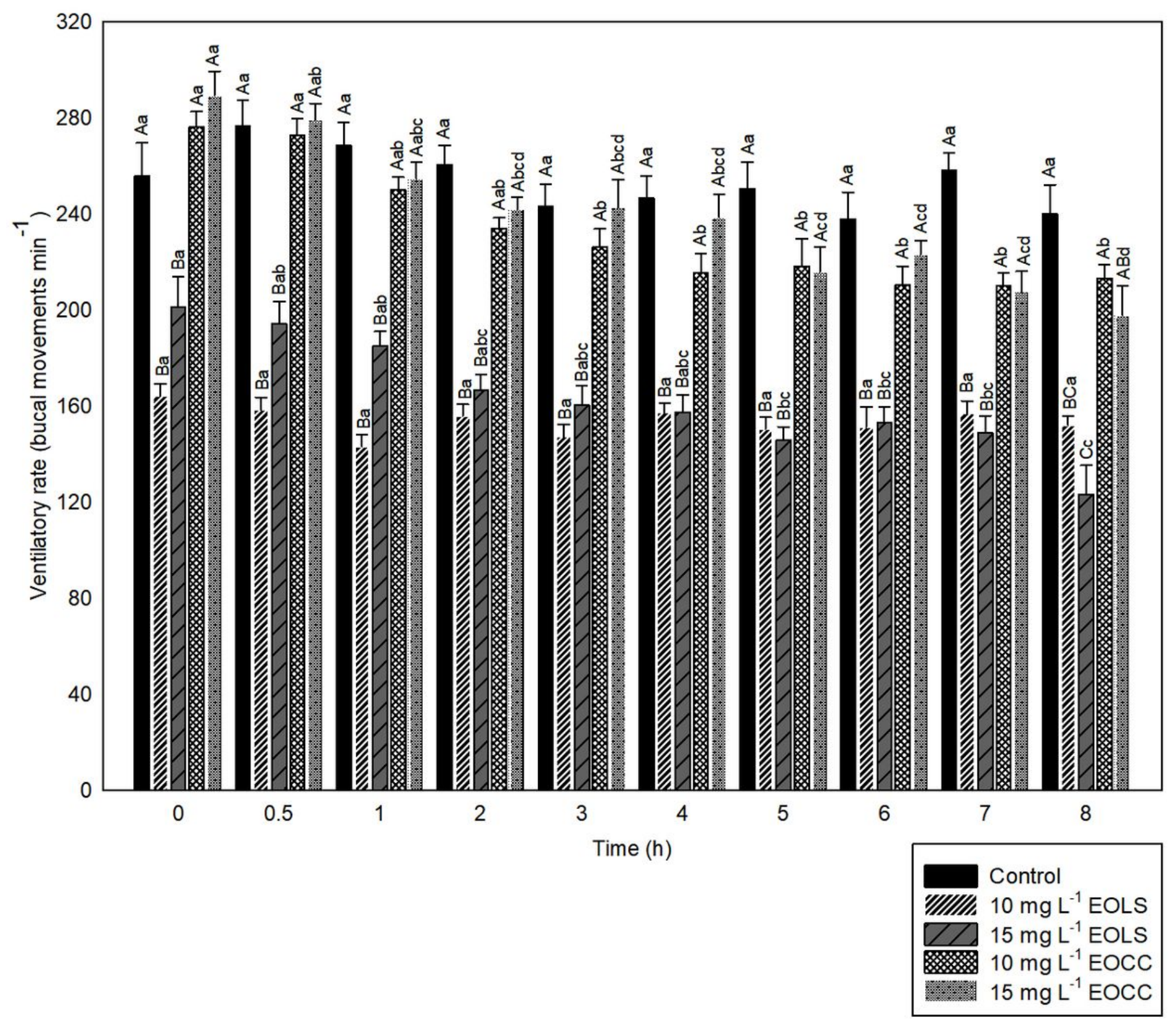

Figure 5

Ventilatory rate in freshwater angelfish (Pterophyllum scalare) juveniles II without and with essential oils from Lippia sidoides (EOLS) and Cymbopogon citratus (EOCC) added to the water in different times of exposure. Data are expressed as mean \pm SEM ( $n=4$ plastic bags per treatment) ( $n=8$ fish per treatment). Different capital letters indicate significant differences between different treatments at the same time $(p<0.05)$. Different lowercase letters indicate significant differences between different times at the same treatment $(p<0.05)$ 